\title{
A Study on Mn-Fe Catalysts Supported on Coal Fly Ash for Low-Temperature Selective Catalytic Reduction of $\mathrm{NO}_{X}$ in Flue Gas
}

\author{
Xiaoxu Duan ${ }^{1}$, Jinxiao Dou ${ }^{1, *}$, Yongqi Zhao ${ }^{1}$, Salman Khoshk Rish ${ }^{1,2}$ and Jianglong Yu ${ }^{1,2, *(1)}$ \\ 1 Key Laboratory of Advanced Coal and Coking Technology of Liaoning Province, \\ School of Chemical Engineering, University of Science and Technology Liaoning, Anshan 114051, China; \\ xiaoxuduan@ustl.edu.cn (X.D.); yongqizhao@ustl.edu.cn (Y.Z.); salmankhoshkrish@ustl.edu.cn (S.K.R.) \\ 2 Chemical Engineering, University of Newcastle, Callaghan, NSW 2308, Australia \\ * Correspondence: doujx123@ustl.edu.cn (J.D.); jianglong.yu@newcastle.edu.au (J.Y.)
}

Received: 28 October 2020; Accepted: 27 November 2020; Published: 30 November 2020

\begin{abstract}
A series of $\mathrm{Mn}_{0.15} \mathrm{Fe}_{0.05} /$ fly-ash catalysts have been synthesized by the co-precipitation method using coal fly ash (FA) as the catalyst carrier. The catalyst showed high catalytic activity for low-temperature selective catalytic reduction (LTSCR) of $\mathrm{NO}$ with $\mathrm{NH}_{3}$. The catalytic reaction experiments were carried out using a lab-scale fixed-bed reactor. De- $\mathrm{NO}_{\mathrm{x}}$ experimental results showed the use of optimum weight ratio of $\mathrm{Mn} / \mathrm{FA}$ and $\mathrm{Fe} / \mathrm{FA}$, resulted in high $\mathrm{NH}_{3}$-SCR (selective catalytic reduction) activity with a broad operating temperature range $\left(130-300{ }^{\circ} \mathrm{C}\right)$ under $50000 \mathrm{~h}^{-1}$. Various characterization methods were used to understand the role of the physicochemical structure of the synthesized catalysts on their De- $\mathrm{NO}_{x}$ capability. The scanning electron microscopy, physical adsorption-desorption, and X-ray photoelectron spectroscopy showed the interaction among the $\mathrm{MnO}_{\mathrm{x}}, \mathrm{FeO}_{\mathrm{x}}$, and the substrate increased the surface area, the amount of high valence metal state $\left(\mathrm{Mn}^{4+}\right.$, $\mathrm{Mn}^{3+}$, and $\left.\mathrm{Fe}^{3+}\right)$, and the surface adsorbed oxygen. Hence, redox cycles $\left(\mathrm{Fe}^{3+}+\mathrm{Mn}^{2+} \leftrightarrow \mathrm{Mn}^{3+}+\mathrm{Fe}^{2+}\right.$; $\mathrm{Fe}^{2+}+\mathrm{Mn}^{4+} \leftrightarrow \mathrm{Mn}^{3+}+\mathrm{Fe}^{3+}$ ) were co-promoted over the catalyst. The balance between the adsorption ability of the reactants and the redox ability can promote the excellent $\mathrm{NO}_{\mathrm{x}}$ conversion ability of the catalyst at low temperatures. Furthermore, $\mathrm{NH}_{3} / \mathrm{NO}$ temperature-programmed desorption, $\mathrm{NH}_{3} / \mathrm{NO}$ - thermo gravimetric-mass spectrometry $\left(\mathrm{NH}_{3} / \mathrm{NO}-\mathrm{TG}-\mathrm{MS}\right.$ ), and in-situ DRIFTs (Diffuse

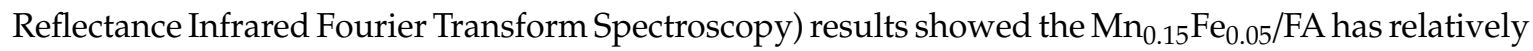
high adsorption capacity and activation capability of reactants $\left(\mathrm{NO}, \mathrm{O}_{2}\right.$, and $\left.\mathrm{NH}_{3}\right)$ at low temperatures. These results also showed that the Langmuir-Hinshelwood $(\mathrm{L}-\mathrm{H})$ reaction mechanism is the main reaction mechanism through which $\mathrm{NH}_{3}$-SCR reactions took place. This work is important for synthesizing an efficient and environmentally-friendly catalyst and demonstrates a promising waste-utilization strategy.
\end{abstract}

Keywords: coal fly ash; $\mathrm{Mn}_{0.15} \mathrm{Fe}_{0.05} / \mathrm{FA}$ catalysts; low-temperature SCR; De- $\mathrm{NO}_{x}$ efficiency; co-impregnation method

\section{Introduction}

Coal, as a fuel, has played a vital role in the development of the world's economy. Coal fly ash production resulting from coal combustion is ecologically problematic, and every year millions of tons of fly ash are produced [1]. Also, the emission of environmentally harmful gases, e.g., $\mathrm{NO}_{\mathrm{x}}$, has been a global concern, where coal combustion is responsible for most of the emissions. In 2017, the $\mathrm{NO}_{\mathrm{x}}$ emissions of China alone reached 12.59 million tons, with $67.6 \%$ from stationary sources (China Statistical Yearbook 2019). High concentrations of $\mathrm{NO}_{x}$ gases in the atmosphere is environmentally 
problematic, which is directly responsible for photochemical smog, ozone deterioration, and acid rain $[2,3]$. With the implementation of strict environmental policies, the $\mathrm{NO}_{\mathrm{x}}$ emissions of coal-fired power plants have been limited to $100 \mathrm{mg} \cdot \mathrm{m}^{-3}$ (GB13223-2011). Other factories like steel refineries (GB28662-2012) and cement plants (GB4915-2013) are limited to $300 \mathrm{mg} \cdot \mathrm{m}^{-3}$, while glass factories get $700 \mathrm{mg} \cdot \mathrm{m}^{-3}$ (GB26453-2011).

Currently, selective catalytic reduction by $\mathrm{NH}_{3}\left(\mathrm{NH}_{3}-\mathrm{SCR}\right)$ is a developed and effective technology studied for many years. Typically, $\mathrm{NH}_{3}-\mathrm{SCR}$ catalysts contain a mixture of metal ions, and $\mathrm{V}-\mathrm{W}(\mathrm{Mo}) / \mathrm{Ti}$ catalyst is the most efficient commercial SCR catalyst [4]. The catalyst unit is usually placed upstream of the electrostatic precipitator (ESP) and desulfurization unit because of its high operating temperature $\left(300-400{ }^{\circ} \mathrm{C}\right)$. This placement shortens the catalyst's life due to poisoning by fly ash and sulfur dioxide present in the flue gas. This issue has been addressed by placing the catalyst downstream the ESP and desulphurization unit. While the temperatures in the downstream unit are significantly below the activation temperature of the commercial catalyst $(\mathrm{V}-\mathrm{W}(\mathrm{Mo}) / \mathrm{Ti})$, the way to mitigate this issue is either by pre-heating the flue gas or by changing the tail system, which is a significant financial burden [5]. Therefore, there is the necessity for an efficient and environmentally-friendly catalyst, which has a low-temperature activation $\left(<200^{\circ} \mathrm{C}\right)$ that can effectively be placed downstream of the ESP and desulfurization unit.

Until recent years, transition metals have gained considerable attention for their excellent catalytic property. Mn-based catalysts have attracted significant attention due to their great low-temperature De- $\mathrm{NO}_{\mathrm{x}}$ capability and the diversity of valence states [2,6]. However, the introduction of another transition metal could further increase the $\mathrm{NH}_{3}$-SCR ability at low temperatures, such as the combination of manganese and iron. Many studies have used the hydrothermal impregnation method to synthesize catalysts with special morphological structure, such as Fe-OMS-2 with a uniform nanowire morphology [7], MnFe-MOF-74 [8], $\mathrm{MnO}_{x}-\mathrm{FeO}_{x}$ nanoneedles [9], MnFe nanowire [10], $\mathrm{MnFeO}_{\mathrm{x}}$ nanorod [11], $\mathrm{MnCeFeTiO}_{\mathrm{x}}$ microsphere, and $\mathrm{MnFeO}_{\mathrm{x}}-\mathrm{MOFs}$ [12]. Some other studies have coprecipitated Mn-Fe into different commercial carriers $[2,6,8,13,14]$, such as $\mathrm{FeMnTiO}_{\mathbf{x}}[6]$, $\mathrm{Mn}-\mathrm{Fe} / \mathrm{TiO}_{2}$ [13], Fe-Mn/SBA-15 [14], and Mn-Fe@ceramics [8]. These catalysts can achieve a maximum $\mathrm{NO}_{\mathrm{x}}$ conversion of $86.8 \%$ at $210{ }^{\circ} \mathrm{C}$. Furthermore, López-Hernández et al. [15] prepared a series of $\mathrm{Mn}-\mathrm{Fe}$ catalysts loaded on different carriers and found that the activity of the catalysts is highly dependent on the structure and acidity of the carriers. Therefore, the carrier selected is of high importance, influencing the performance of the catalyst. However, there are still some setbacks for SCR technology: They are expensive, time-consuming, and complex.

In recent years, the accumulation of large quantities of FA has caused significant ecological challenges; every year, 800 million tons of FA is produced worldwide [1]. In China, about $67 \%$ of FA is used in various industries. The remaining FA is mostly disposed of under the dams during construction, threatening living organisms [16]. Thus, a safe and cost-effective technique is vital to utilize excess FA. Value-added products are among the best strategies researchers have been employing to convert FA into high-value materials [17], such as arsenic adsorbent [18] and wastewater treatment agents [19]. Chen et al. [20] synthesized a catalyst by loading Mn-Ce oxides on pretreated-FA, which had an operating temperature range of $200-300{ }^{\circ} \mathrm{C}$. Li et al. [14] used FA to produce a molecular sieve (SBA-15) and then used the impregnation method to synthesis Fe-Mn/SBA-15 catalyst, which possessed an excellent De- $\mathrm{NO}_{x}$ activity in the temperature range of $180-300^{\circ} \mathrm{C}$ [21]. In another study, the authors used the co-precipitation method to load Mn-Ce onto a carrier composed of a mixture of FA and Ca-based bentonite to synthesize a catalyst that could adsorb and reduce $\mathrm{NO}$ at $60 \%$ for $18 \mathrm{~min}$. Cui et al. [22] used sulfuric acid to activate fly ash as a silica-based sulfuric acid catalyst, which could achieve $\mathrm{SO}_{2}$ and $\mathrm{NO}$ removal by $\mathrm{H}_{2} \mathrm{O}_{2}$ gas. Although significant research efforts have been focused on the utilization of FA as De- $\mathrm{NO}_{x}$ catalyst, the literature still lacks an intuitive, cost-effective, and environmentally-friendly catalyst with excellent catalytic performance.

From the economic point of view, and based on the previous studies, we present an intuitive one-step co-impregnation method to prepare a group of $\mathrm{Mn}_{x} \mathrm{Fe}_{\mathrm{y}} / \mathrm{FA}$ catalysts with excellent $\mathrm{NH}_{3}$-LTSCR 
efficiency. This catalyst could solve two of the most important setbacks of coal combustion, where the produced waste $\mathrm{FA}$, after simple treatment, could be used to remove $\mathrm{NO}_{\mathrm{x}}$ from flue gas emissions through a straightforward, environmentally-friendly and cost-effective synthesis method. Also, the catalytic performance and reaction pathways were determined by various characterization methods.

\section{Results and Discussion}

\subsection{The Morphology and Structure of Catalysts}

The physical structure of the catalysts was studied by SEM technique and the $\mathrm{N}_{2}$ physisorption analysis. The results are given in Figures S1 and S2 (summarized in Table 1). These results correlate to a great extent. From the SEM images (Figure S1) of the various catalysts, a large number of debris or/and cracks can be observed on the surface. FA had a smooth surface with minimum irregularities resulting in low surface area $\left(7.7 \mathrm{~m}^{2} \cdot \mathrm{g}^{-1}\right)$ and total pore volume $\left(0.1 \mathrm{~cm}^{3} \cdot \mathrm{g}^{-1}\right) . \mathrm{Fe}_{0.10} / \mathrm{FA}$ had larger openings or holes on the surface. Its surface area and total pore volume reached $35.8 \mathrm{~m}^{2} \cdot \mathrm{g}^{-1}$ and $0.1 \mathrm{~cm}^{3} \cdot \mathrm{g}^{-1}$, respectively. The presence of micro-particles on $\mathrm{Mn}_{0.15} / \mathrm{FA}$ surface resulted in a high surface area value of $78.0 \mathrm{~m}^{2} \cdot \mathrm{g}^{-1}$. For $\mathrm{Mn}_{\mathrm{x}} \mathrm{Fe}_{0.10} / \mathrm{FA}$, when the loading amount of $\mathrm{Mn}$ was lower than 0.15 , more pores were observed. However, when Mn content was further increased to 0.20 , dense and bonding pores were formed. For $\mathrm{Mn}_{0.15} \mathrm{Fe}_{\mathrm{y}} / \mathrm{FA}$, when the loading amount of $\mathrm{Fe} / \mathrm{FA}$ was lower than 0.1 , less porous structures were formed. The increase of $\mathrm{FeO}_{\mathrm{x}}$ led to the formation of a highly porous structure. In comparison, the surface morphology of $\mathrm{Mn}_{0.15} \mathrm{Fe}_{0.05} / \mathrm{FA}$ varied significantly with the growth of numerous screw-like structures appearing on the surface, as shown in Figure S1g, resulting in a high surface area value of $91.6 \mathrm{~m}^{2} \cdot \mathrm{g}^{-1}$ and a total pore volume of $0.15 \mathrm{~cm}^{3} \cdot \mathrm{g}^{-1}$. The interaction between $\mathrm{MnO}_{\mathrm{x}}, \mathrm{FeO}_{\mathrm{x}}$, and the carrier changes the micro-morphology and the physical structure of the samples [23,24].

Table 1. Surface species and physical properties of $\mathrm{Mn}_{x} \mathrm{Fe}_{\mathrm{y}} / \mathrm{FA}$ samples.

\begin{tabular}{|c|c|c|c|c|c|c|c|c|c|}
\hline \multirow[b]{2}{*}{ Sample } & \multicolumn{2}{|c|}{ Elements/wt. $\%^{a}$} & \multicolumn{3}{|c|}{$\begin{array}{c}\text { Surface Atomic } \\
\text { Concentration } / \% \text { b }\end{array}$} & \multicolumn{3}{|c|}{ Physical Properties ${ }^{c}$} & \multirow{2}{*}{$\begin{array}{l}\text { The Average } \\
\text { Crystallite Size } \\
\text { of } \mathrm{SiO}_{2}(\mathrm{~nm})^{d}\end{array}$} \\
\hline & $\mathrm{Fe} / \mathrm{FA}$ & Mn/FA & $\mathrm{Fe}$ & Mn & $\mathbf{O}$ & $\begin{array}{c}\mathrm{S}_{\mathrm{BET}} \\
\left(\mathrm{m}^{2} / \mathrm{g}\right)\end{array}$ & $\begin{array}{c}\text { Average } \\
\text { Pore Size } \\
\text { (nm) }\end{array}$ & $\begin{array}{l}V_{\text {Total }} \\
\left(\mathrm{cm}^{3} / \mathrm{g}\right)\end{array}$ & \\
\hline FA & 4.5 & 0.1 & 2.2 & 6.6 & 91.2 & 7.7 & 12.7 & 0.1 & 71.1 \\
\hline $\mathrm{Mn}_{0.15} / \mathrm{FA}$ & 3.1 & 15.1 & 1.5 & 15.2 & 83.3 & 78.0 & 3.1 & 0.1 & 62.7 \\
\hline $\mathrm{Fe}_{0.10} / \mathrm{FA}$ & 13.4 & 0.1 & 12.2 & 1.8 & 88.7 & 35.8 & 6.5 & 0.1 & 49.8 \\
\hline $\mathrm{Mn}_{0.05} \mathrm{Fe}_{0.10} / \mathrm{FA}$ & 13.7 & 5.0 & 9.6 & 6.9 & 83.5 & 46.4 & 5.4 & 0.1 & 52.4 \\
\hline $\mathrm{Mn}_{0.15} \mathrm{Fe}_{0.10} / \mathrm{FA}$ & 10.8 & 14.4 & 5.9 & 16.7 & 77.4 & 85.3 & 3.5 & 0.2 & 57.7 \\
\hline $\mathrm{Mn}_{0.20} \mathrm{Fe}_{0.10} / \mathrm{FA}$ & 13.0 & 19.7 & 5.5 & 22.4 & 72.2 & 64.6 & 4.6 & 0.2 & 70.5 \\
\hline $\mathrm{Mn}_{0.15} \mathrm{Fe}_{0.05} / \mathrm{FA}$ & 8.5 & 14.9 & 3.8 & 16.1 & 80.1 & 91.6 & 3.4 & 0.2 & 53.1 \\
\hline
\end{tabular}

${ }^{a}$ Element compositions measured by using ICP-OES; ${ }^{b}$ Surface atomic concentration calculated by XPS; ${ }^{c}$ Physical properties calculated by $\mathrm{N}_{2}$ physisorption. ${ }^{\mathrm{d}}$ Crystallite size of $\mathrm{SiO}_{2}$ calculated by the Debye-Scherrer equation.

The $\mathrm{N}_{2}$ physisorption analysis was used to understand the change of the physical structure of the catalysts caused by metal oxides. The $\mathrm{N}_{2}$ adsorption/desorption isotherms of different samples are given in Figure S2. Notably, the curves of all samples are following the type IV isotherms with type H3 hysteresis loops, which corresponds to the micro- and mesoporous structure $[25,26]$. The presence of micro- and mesoporous structure is evident in Figure S2, indicating that the majority of the pores have an opening pore diameter of $6 \mathrm{~nm}$. The main factor contributing to the formation of these microand mesoporous structures is the diffusion of iron oxides and manganese oxide into the lattice of the carrier during the calcination process [23]. These mesoporous materials provide abundant active sites for the adsorption of reactants, which facilitates the mass transfer process at the gas-solid phase boundary [26]. Efficient mass transfer plays a vital role during the bulk reaction and lowering the energy required for the $\mathrm{NH}_{3}$-SCR reaction. The $\mathrm{N}_{2}$ desorption capacity of all samples followed the order of $\mathrm{Mn}_{0.15} \mathrm{Fe}_{0.05} / \mathrm{FA}>\mathrm{Mn}_{0.15} / \mathrm{FA}>\mathrm{Fe}_{0.10} / \mathrm{FA}>\mathrm{FA}$. It is evident that, with the doping of metal 
oxide, the internal structure of samples became more copious than that of the FA, and the larger specific surface area of $\mathrm{Mn}_{0.15} \mathrm{Fe}_{0.05} / \mathrm{FA}$ provides more active sites than others.

\subsection{Catalytic Reactivity during Low-Temperature SCR Reactions}

Figure 1 shows the catalytic activities of $\mathrm{Mn}_{\mathrm{x}} \mathrm{Fe}_{\mathrm{y}} / \mathrm{FA}$ catalysts at different temperatures. Where $\mathrm{x}$ is the weight ratio of $\mathrm{Mn}$ to $\mathrm{FA}$, and $\mathrm{y}$ is the weight ratio of $\mathrm{Fe}$ to FA. The activity of $\mathrm{Fe}_{0.10} / \mathrm{FA}$ by Mn doping with " $\mathrm{x}$ " ranging from 0.05 to 0.2 at a GHSV of $50,000 \mathrm{~h}^{-1}$ is shown in Figure $1 \mathrm{a}$. The as-obtained FA showed a weak De- $\mathrm{NO}_{x}$ activity at the designed experimental temperatures, with the highest De-NO $\mathrm{N}_{\mathrm{x}}$ efficiency of $\sim 23.95 \%$ recorded at $300{ }^{\circ} \mathrm{C}$. This is due to the natural structure and surface property of FA [15], which will be demonstrated in the following sections. After the addition of Fe (weight ratio of 0.10 ), slightly higher De- $\mathrm{NO}_{\mathrm{x}}$ activity was recorded. These results indicate that the introduction of Fe did not contribute much to the De- $\mathrm{NO}_{\mathrm{x}}$ activity of $\mathrm{Fe}_{0.10} / \mathrm{FA}$. However, the introduction of $\mathrm{Mn}$ into $\mathrm{Fe}_{0.10} / \mathrm{FA}$ notably improved its SCR activity, and the graphed $\mathrm{NO}_{\mathrm{x}}$ conversion data of all the samples show a "volcanic" shape (Figure 1a). As the ratio of $\mathrm{Mn}$ was increased to $0.15, \mathrm{De}-\mathrm{NO}_{\mathrm{x}}$ activity increased, and further addition of $\mathrm{Mn}$ led to a decrease in conversion efficiency. De- $\mathrm{NO}_{\mathrm{x}}$ efficiency of different samples increased as follows: $\mathrm{FA}<\mathrm{Fe}_{0.10} / \mathrm{FA}<\mathrm{Mn}_{0.05} \mathrm{Fe}_{0.10} / \mathrm{FA}<\mathrm{Mn}_{0.20} \mathrm{Fe}_{0.10} / \mathrm{FA}<\mathrm{Mn}_{0.10} \mathrm{Fe}_{0.10} / \mathrm{FA}<\mathrm{Mn}_{0.15} \mathrm{Fe}_{0.10} / \mathrm{FA}$. The temperature range in which the $\mathrm{NO}_{x}$ conversion efficiency reaches $80 \%\left(\mathrm{~T}_{80}\right)$ was considered as a primary indicator, and when conversion efficiency has reached $50 \%\left(T_{50}\right)$, that temperature is considered as the activation temperature of $\mathrm{NH}_{3}$-SCR activity. Among these samples, the catalytic activity of $\mathrm{Mn}_{0.15} \mathrm{Fe}_{0.10} / \mathrm{FA}$ shows high conversion efficiency, with the lowest $\mathrm{T}_{50}$ at $108{ }^{\circ} \mathrm{C}$ and the broadest $\mathrm{T}_{80}$ at $145-300{ }^{\circ} \mathrm{C}$. Indicating that $\mathrm{Mn}_{0.15} \mathrm{Fe}_{0.10} / \mathrm{FA}$ exhibits great potential as an LTSCR catalyst $\left(100-250^{\circ} \mathrm{C}\right)$, and the mass ratio of $\mathrm{Mn} / \mathrm{FA}$ was fixed at 0.15 .
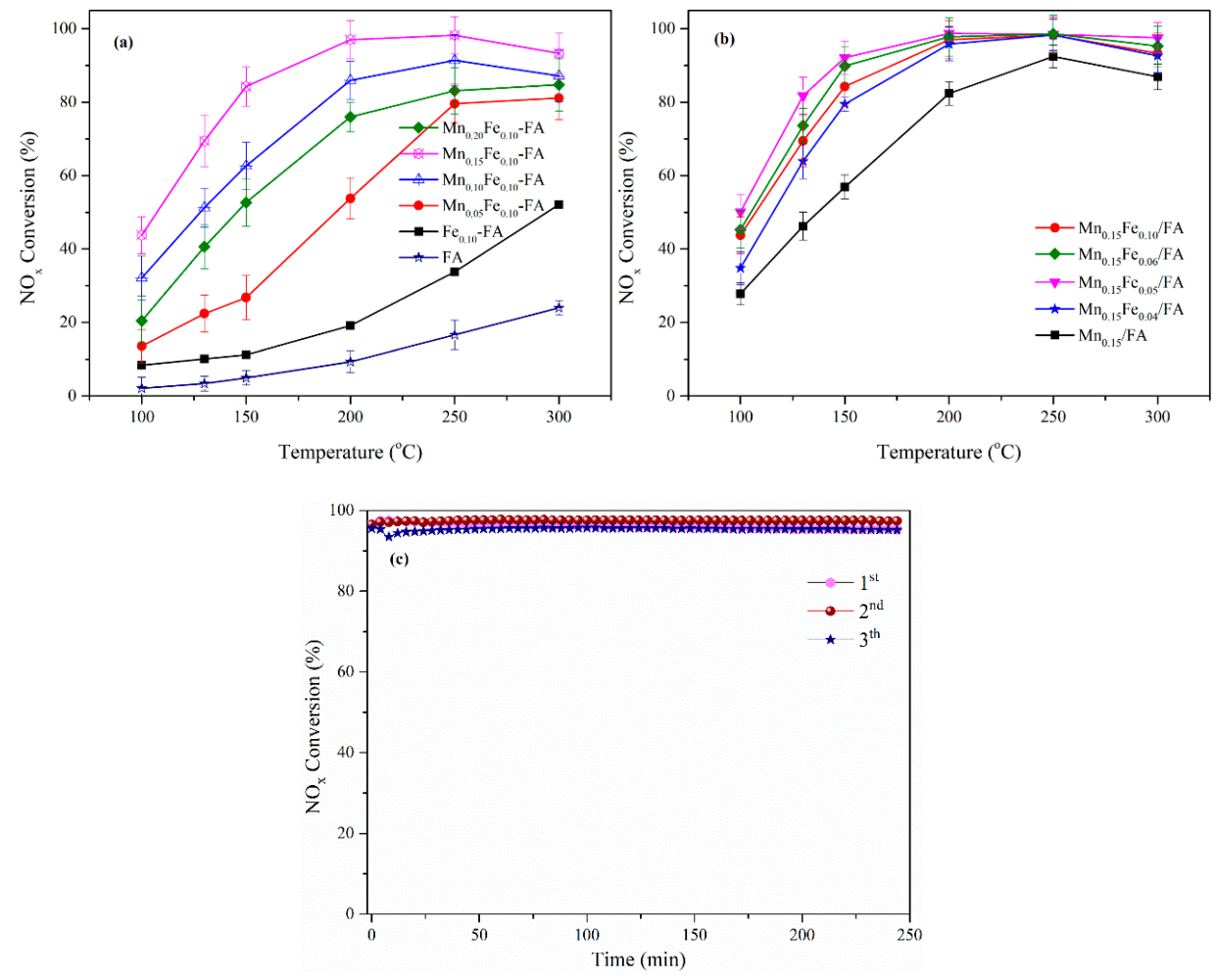

Figure 1. $\mathrm{NO}_{\mathrm{x}}$ Conversion during the $\mathrm{NH}_{3}$-SCR process over $\mathrm{Mn}_{\mathrm{x}} \mathrm{Fe}_{0.10} / \mathrm{FA}$ with different $\mathrm{Mn}$ content $(\mathrm{x}=0,0.05,0.10,0.15$, and 0.20$)(\mathbf{a})$ and $\mathrm{Mn}_{0.15} \mathrm{Fe}_{\mathrm{y}} / \mathrm{FA}$ with different Fe content $(\mathrm{y}=0,0.04,0.05,0.06$, and 0.10$)(\mathbf{b})$; and the stability of the $\mathrm{Mn}_{0.15} \mathrm{Fe}_{0.05} / \mathrm{FA}$ catalyst at $200{ }^{\circ} \mathrm{C}$ (c). Experimental conditions: $1000 \mathrm{ppm}$ of $\mathrm{NO}, 1000 \mathrm{pp}$ of $\mathrm{NH}_{3}, 5 \mathrm{vol} . \% \mathrm{O}_{2}$ and $\mathrm{N}_{2}$ as the balance gas, GHSV of $50,000 \mathrm{~h}^{-1}$. 
Then, the ratio of $\mathrm{FeO}_{\mathrm{x}}$ in the $\mathrm{Mn}_{0.15} \mathrm{Fe}_{\mathrm{y}} / \mathrm{FA}$ catalyst was varied and optimized to improve its efficiency and obtain the most efficient LTSCR catalyst. The De- $\mathrm{NO}_{\mathrm{x}}$ activity of $\mathrm{Mn}_{0.15} \mathrm{Fe}_{\mathrm{y}} / \mathrm{FA}$ is given in Figure $1 \mathrm{~b}$. Compared with $\mathrm{Mn}_{0.15} / \mathrm{FA}$, the $\mathrm{NO}_{x}$ efficiency of all catalysts was further improved at the desired temperatures $\left(100-300{ }^{\circ} \mathrm{C}\right)$. The conversion efficiency improved as the Fe content increased to 0.05 , and then declined with a further increase in the ratio of Fe. The best activity was obtained from the $\mathrm{Mn}_{0.15} \mathrm{Fe}_{0.05} / \mathrm{FA}$ during the whole operating temperature range, which has the lowest $\mathrm{T}_{50}\left(100^{\circ} \mathrm{C}\right)$ and the broadest $\mathrm{T}_{80}\left(130-300{ }^{\circ} \mathrm{C}\right)$. Moreover, over $90 \%$ of $\mathrm{NO}_{\mathrm{x}}$ conversion was obtained between 147 and $300{ }^{\circ} \mathrm{C}$. The final weight ratio of $\mathrm{FeO}_{x}(0.05)$ and $\mathrm{MnO}_{x}(0.15)$ achieved a high catalytic activity. In comparison (Table 2), the $\mathrm{Mn}_{0.15} \mathrm{Fe}_{0.05} / \mathrm{FA}$ has been successfully synthesized by a straightforward method. The stability results of the catalyst are shown in Figure 1c. It can be seen that after 4 hours and three cycles, the $\mathrm{Mn}_{0.15} \mathrm{Fe}_{0.05} / \mathrm{FA}$ catalyst exhibited excellent stability with long stable catalytic activity and good regenerability.

Table 2. Summary of typical $\mathrm{MnFeO}_{x}$ oxide catalysts used for the $\mathrm{NH}_{3}-\mathrm{SCR}$ process.

\begin{tabular}{|c|c|c|c|c|}
\hline Catalyst & Prepared & $\begin{array}{c}\mathrm{NO}_{\mathrm{x}} \text { Conversion } \\
\left(\mathrm{T}_{80}\right)\end{array}$ & Reaction Condition & Ref. \\
\hline $\mathrm{Mn}_{0.15} \mathrm{Fe}_{0.05} / \mathrm{FA}$ & Co-precipitation & $130-300^{\circ} \mathrm{C}$ & $\begin{array}{c}{[\mathrm{NO}]=\left[\mathrm{NH}_{3}\right]=1000 \mathrm{ppm},\left[\mathrm{O}_{2}\right]=5} \\
\text { vol. } \%, \mathrm{GHSV}=50,000 \mathrm{~h}^{-1}\end{array}$ & This work \\
\hline 11.2Fe-11Mn/SBA-15 & $\begin{array}{c}\text { Wetness } \\
\text { impregnation }\end{array}$ & $180-325^{\circ} \mathrm{C}$ & $\begin{array}{c}{[\mathrm{NO}]=\left[\mathrm{NH}_{3}\right]=300 \mathrm{ppm},\left[\mathrm{O}_{2}\right]=3} \\
\text { vol. } \%, \mathrm{GHSV}=\sim 120,000 \mathrm{~h}^{-1}\end{array}$ & [14] \\
\hline $\mathrm{Mn}-\mathrm{Fe} / \mathrm{Al}_{2} \mathrm{O}_{3}$ & $\begin{array}{l}\text { Incipient wetness } \\
\text { impregnation }\end{array}$ & $300^{\circ} \mathrm{C}$ & $\begin{array}{l}{[\mathrm{NO}]=\left[\mathrm{NH}_{3}\right]=500 \mathrm{ppm},\left[\mathrm{O}_{2}\right]=4} \\
\text { vol. } \%, \mathrm{GHSV}=\sim 90,000 \mathrm{~mL} \cdot \mathrm{g}^{-1} \cdot \mathrm{h}^{-1}\end{array}$ & [15] \\
\hline $\mathrm{MnCeFeO}_{\mathrm{x}}-\mathrm{AC}$ & Impregnation & $100-225^{\circ} \mathrm{C}$ & $\begin{array}{c}{[\mathrm{NO}]=\left[\mathrm{NH}_{3}\right]=500 \mathrm{ppm},\left[\mathrm{O}_{2}\right]=11} \\
\text { vol. } \%, \mathrm{GHSV}=12,000 \mathrm{~h}^{-1}\end{array}$ & [9] \\
\hline $\begin{array}{l}\text { Tourmaline-modified } \\
\text { FeMnTiO }_{x}\end{array}$ & Sol-gel & $175-375^{\circ} \mathrm{C}$ & $\begin{array}{c}{[\mathrm{NO}]=\left[\mathrm{NH}_{3}\right]=800 \mathrm{ppm},\left[\mathrm{O}_{2}\right]=8} \\
\text { vol. } \%, \mathrm{GHSV}=50,000 \mathrm{~h}^{-1}\end{array}$ & [27] \\
\hline $\begin{array}{l}\mathrm{FeMnO}_{\mathrm{x}} \mathrm{Mn} \text {-rich } \\
\text { limonite }\end{array}$ & Thermal activation & $130-300{ }^{\circ} \mathrm{C}$ & $\begin{array}{c}{[\mathrm{NO}]=\left[\mathrm{NH}_{3}\right]=1000 \mathrm{ppm},\left[\mathrm{O}_{2}\right]=3} \\
\text { vol. } \%, \mathrm{GHSV}=72,000 \mathrm{~h}^{-1}\end{array}$ & [28] \\
\hline $\begin{array}{l}\mathrm{MnCeFeTiO}_{\mathrm{x}} \\
\text { micro-spherical }\end{array}$ & $\begin{array}{l}\text { Co-precipitation } \\
\text { and spray drying }\end{array}$ & $170-320^{\circ} \mathrm{C}$ & $\begin{array}{c}{[\mathrm{NO}]=\left[\mathrm{NH}_{3}\right]=500 \mathrm{ppm},\left[\mathrm{O}_{2}\right]=5} \\
\text { vol. } \%, \mathrm{GHSV}=40,000 \mathrm{~h}^{-1}\end{array}$ & [29] \\
\hline $\mathrm{MnFeO}_{\mathrm{x}}$ nanorod & Hydrothermal & $130-400^{\circ} \mathrm{C}$ & $\begin{array}{c}{[\mathrm{NO}]=\left[\mathrm{NH}_{3}\right]=500 \mathrm{ppm},\left[\mathrm{O}_{2}\right]=5} \\
\text { vol. } \%, \mathrm{GHSV}=28,000 \mathrm{~h}^{-1}\end{array}$ & [11] \\
\hline MnFe nanowire & Electrospinning & $180-330^{\circ} \mathrm{C}$ & $\begin{array}{c}{[\mathrm{NO}]=\left[\mathrm{NH}_{3}\right]=500 \mathrm{ppm},\left[\mathrm{O}_{2}\right]=5} \\
\text { vol. } \%, \mathrm{GHSV}=36,000 \mathrm{~h}^{-1}\end{array}$ & [10] \\
\hline $\mathrm{MnFeO}_{x}-\mathrm{MOFs}$ & $\begin{array}{l}\text { Hydrothermal } \\
\text { reaction-calcination }\end{array}$ & $150-270^{\circ} \mathrm{C}$ & $\begin{array}{c}{[\mathrm{NO}]=\left[\mathrm{NH}_{3}\right]=500 \mathrm{ppm},\left[\mathrm{O}_{2}\right]=5} \\
\text { vol. } \%, \mathrm{GHSV}=10,000 \mathrm{~h}^{-1}\end{array}$ & [8] \\
\hline
\end{tabular}

\subsection{Reaction Mechanism Analysis}

\subsubsection{Surface Chemical States}

The XRD (X-ray Diffraction) results of the $\mathrm{Mn}_{\mathrm{x}} \mathrm{Fe}_{\mathrm{y}} / \mathrm{FA}$ catalysts are shown in Figure S3. For FA, only the diffraction peaks of $\mathrm{SiO}_{2}$ and weaker $\mathrm{Fe}_{2} \mathrm{O}_{3}$ were observed. As different ratios of $\mathrm{Mn}$ and Fe oxide were doped, no additional peaks besides those of FA were detected. However, ICP-OES (Inductively Coupled Plasma Optical Emission spectroscopy) results (Table 1) show that the mass content of Fe and Mn within all samples is approximately equal to the calculated values, which indicates that the added metal oxide is present in the catalyst. XRD results also showed that the intensity of peaks and the average crystal size assigned to $\mathrm{SiO}_{2}$ decreased with $\mathrm{Mn}$ and $\mathrm{Fe}$ doping, and the peak of $\mathrm{SiO}_{2}$ slightly shifted towards lower $2 \theta$ values. The average crystal size of $\mathrm{SiO}_{2}$ was calculated based on the diffraction peak $(1,0,0)$ according to the Scherrer formula (Table 1$)$. These results indicated that the presence of defective lattice and a decrease in the crystalline size of $\mathrm{SiO}_{2}$, which were caused by the introduction of $\mathrm{Mn}$ and $\mathrm{Fe}$ oxide. This result also shows the strong interaction between $\mathrm{FeO} / \mathrm{MnO}_{\mathrm{x}}$ and the carrier. The defective lattice and the interaction between metal oxides and the carrier led to a more unbalance charge state and oxygen vacancy, providing abundant active sites during the SCR process and contributing to the higher NO conversion ability of the catalyst [5]. 
The valence state of the added metals is of significant importance in the SCR reaction. To further examine the surface chemical states and the types of ion species over catalysts, XPS (X-ray photoelectron spectroscopy) measurement of Fe 2p, Mn 2p, and O 1s in fresh catalysts were conducted (Table 1). The results indicate that the surface concentration of Mn is slightly higher than that in bulk catalysts (from the ICP-OES results), while the concentration of Fe shows the opposite phenomenon. This indicates that $\mathrm{Fe}$ could promote the enrichment of $\mathrm{Mn}$ on the surface, providing more active sites during low-temperature De- $\mathrm{NO}_{x}$ by $\mathrm{NH}_{3}$. The recorded spectra of different elements were fitted into multiple sub-bands according to the multivalent oxide species on the surface by Gaussian-Lorentz fitting of XPS Peak 4.1, and examples of a peak-fitted graph are given in Figure S4. The relative atomic ratios of different elemental states are listed in Table 3.

Table 3. The surface elemental concentration of catalysts by XPS analysis.

\begin{tabular}{|c|c|c|c|c|c|c|}
\hline \multirow{2}{*}{ Catalyst } & \multicolumn{2}{|c|}{ Mn $2 p_{3 / 2}(e V)$} & \multirow{2}{*}{$\frac{\mathrm{Fe} 2 \mathrm{p}_{3 / 2}(\mathrm{eV})}{\mathrm{Fe}^{3+} / \mathrm{Fe}^{\mathrm{n}+}}$} & \multicolumn{3}{|c|}{ O 1s (eV) } \\
\hline & $\mathrm{Mn}^{4+} / \mathrm{Mn}^{\mathrm{n}+}$ & $\mathrm{Mn}^{3+} / \mathrm{Mn}^{\mathrm{n}+}$ & & $\mathrm{O}_{\text {surf }} / \mathrm{O}_{\mathrm{t}}$ & $\mathbf{O}_{\text {ads }} / \mathrm{O}_{\mathrm{t}}$ & $\mathrm{O}_{\alpha} / \mathrm{O}_{\mathrm{t}}$ \\
\hline $\mathrm{Fe}_{0.10 /} \mathrm{FA}$ & - & - & 66.21 & 23.94 & 48.85 & 72.79 \\
\hline $\mathrm{Mn}_{0.05} \mathrm{Fe}_{0.10} / \mathrm{FA}$ & 33.44 & 48.98 & 69.99 & 23.65 & 47.59 & 71.24 \\
\hline $\mathrm{Mn}_{0.15} \mathrm{Fe}_{0.10} / \mathrm{FA}$ & 36.92 & 49.18 & 69.38 & 16.27 & 46.88 & 63.15 \\
\hline $\mathrm{Mn}_{0.20} \mathrm{Fe}_{0.10} / \mathrm{FA}$ & 33.26 & 49.21 & 52.27 & 17.31 & 44.36 & 61.67 \\
\hline $\mathrm{Mn}_{0.15} / \mathrm{FA}$ & 37.09 & 48.13 & - & 29.26 & 44.17 & 73.43 \\
\hline $\mathrm{Mn}_{0.15} \mathrm{Fe}_{0.05} / \mathrm{FA}$ & 39.59 & 48.38 & 65.45 & 22.78 & 42.4 & 65.18 \\
\hline
\end{tabular}

The overlapped Mn 2p peaks were deconvoluted into three pairs of peaks. The fitted peaks are assigned to $\mathrm{Mn}^{4+}$ (643.58 and $\left.654.71 \mathrm{eV}\right), \mathrm{Mn}^{3+}(642.26$ and $653.6 \mathrm{eV})$, and $\mathrm{Mn}^{2+}(641.21$ and $652.5 \mathrm{eV}$ ). Figure $\mathrm{S} 4 \mathrm{a}$ shows that three valence states of $\mathrm{Mn}$ species within the series of $\mathrm{Mn}_{\mathrm{x}} \mathrm{Fe}_{\mathrm{y}} / \mathrm{FA}$ vary significantly with different ratios of $\mathrm{MnO}_{\mathrm{x}}$ and $\mathrm{FeO}_{\mathrm{x}}$. It was found that the ratio of $\mathrm{Mn}^{4+} / \mathrm{Mn}^{\mathrm{n}}$ first increased and then decreased, and the ratio of $\mathrm{Mn}^{3+} / \mathrm{Mn}^{\mathrm{n}+}$ slightly increased as the ratios of $\mathrm{MnO}_{\mathrm{x}}$ and $\mathrm{FeO}_{\mathrm{x}}$ increased. $\mathrm{Mn}_{0.15} \mathrm{Fe}_{0.05} / \mathrm{FA}$ has the highest ratio of $\mathrm{Mn}^{4+} / \mathrm{Mn}^{\mathrm{n}+}$ value $(39.59 \%)$ and a high ratio of $\mathrm{Mn}^{3+} / \mathrm{Mn}^{\mathrm{n}+}(48.38 \%)$ within all samples. Among the catalysts, most of the Mn exists at high valence states $\left(\mathrm{Mn}^{3+}, \mathrm{Mn}^{4+}\right)$, which is caused by the oxidation of lower valence state $\left(\mathrm{Mn}^{2+}\right)$ contemporary leading to an electronic transfer, such as $\mathrm{Mn}^{4+} \leftrightarrow \mathrm{Mn}^{3+} \leftrightarrow \mathrm{Mn}^{2+}$. The order of the LTSCR activity from high to low is as follows: $\mathrm{MnO}_{2}>\mathrm{Mn}_{5} \mathrm{O}_{8}>\mathrm{Mn}_{2} \mathrm{O}_{3}>\mathrm{Mn}_{3} \mathrm{O}_{4}>\mathrm{MnO}$ [30]. Furthermore, Mn has a high self-redox tendency leading to the formation of a large amount of higher valence state $\mathrm{MnO}_{\mathbf{x}}$ [31] . Many studies have indicated that $\mathrm{Mn}^{4+}$ is the main factor in promoting the oxidation of $\mathrm{NO}$ to $\mathrm{NO}_{2}$ during LTSCR. The co-existence of $\mathrm{NO}_{2}$ and $\mathrm{NH}_{3}$ in one circle can promote the LTSCR process through "fast reaction" [32]:

$$
4 \mathrm{NH}_{3}+2 \mathrm{NO}_{2}+\mathrm{O}_{2} \rightarrow 3 \mathrm{~N}_{2}+6 \mathrm{H}_{2} \mathrm{O} .
$$

The Fe 2p spectra were deconvoluted into different valence states of Fe: $\mathrm{Fe}^{3+}(\sim 725.1$ and $\sim 711.8 \mathrm{eV})$, $\mathrm{Fe}^{2+}(\sim 723.5$ and 710.1), and the satellite peak located at $718.5 \mathrm{eV}$ [33]. Table 3 shows that most Fe species exist in the valence state of $\mathrm{Fe}^{3+}$. With the addition of $\mathrm{MnO}_{\mathrm{x}}$ into $\mathrm{Fe}_{0.10} / \mathrm{FA}$, the ratio of $\mathrm{Fe}^{3+} / \mathrm{Fe}$ increased first and then decreased when the value of $\mathrm{Mn} / \mathrm{FA}$ was higher than 0.15 . However, when $\mathrm{FeO}_{\mathrm{x}}$ was added to $\mathrm{Mn}_{0.15} / \mathrm{FA}$, the ratio of $\mathrm{Fe}^{3+} / \mathrm{Fe}$ also increased. This phenomenon indicates that the ratio of $\mathrm{Mn} / \mathrm{Fe}$ is a critical factor in determining the catalytic capability of a catalyst during LTSCR reactions, and the optimum ratio of $\mathrm{Mn} / \mathrm{Fe}$ could promote the cycle of redox as follows:

$$
\begin{aligned}
& \mathrm{Fe}^{3+}+\mathrm{Mn}^{2+} \leftrightarrow \mathrm{Mn}^{3+}+\mathrm{Fe}^{2+} \\
& \mathrm{Fe}^{2+}+\mathrm{Mn}^{4+} \leftrightarrow \mathrm{Mn}^{3+}+\mathrm{Fe}^{3+} .
\end{aligned}
$$

The transfer of electrons creates an unbalanced charge and underfilled chemical bonds, making it easier to produce oxygen vacancies and highly mobile oxygen. Highly mobile oxygen that is chemically adsorbed on the surface is one of the critical active species during the $\mathrm{NH}_{3}-\mathrm{SCR}$ reaction [24]. 
The O 1s spectra were fitted with three sub-peaks [34]. The peak at $\sim 529.9 \mathrm{eV}$ represents the lattice oxygen (named as $\left.\mathrm{O}_{\beta}\right)$. Defective metal-oxide $(\sim 531.4 \mathrm{eV})$ and chemisorbed water $\left(\sim 532.7 \mathrm{eV}\left(\mathrm{OH}^{-}\right.\right.$ or $\left.\left.\mathrm{H}_{2} \mathrm{O}\right)\right)[35,36]$ are assigned to the chemically absorbed oxygen species on the surface $\left(\mathrm{O}_{\alpha}\right)$. Table 3 shows that the chemically absorbed oxygen is the main form of oxygen species and is more reactive due to higher mobility, lower bonding energy to the surface, and a higher tendency to form $\mathrm{NO}_{2}$ by oxidizing NO; which could promote "fast reaction" [37]. Furthermore, chemically adsorbed oxygen can activate oxygen gas [38], providing sufficient active oxygen species, ensuring fast recovery from low-state metal ion: $\mathrm{Mn}^{3+}+0.5 \mathrm{O}_{2} \rightarrow \mathrm{Mn}^{4+}+\mathrm{O}^{2-}, \mathrm{Fe}^{2+}+0.5 \mathrm{O}_{2} \rightarrow \mathrm{Fe}^{3+}+\mathrm{O}^{2-}$ [39], which facilitate the excellent LTSCR.

Among all the synthesized catalysts, the active components within $\mathrm{Mn}_{0.15} \mathrm{Fe}_{0.05} / \mathrm{FA}$ possess the lowest energy value (Table S1), caused by high electron cloud density. This phenomenon may have been caused by two factors: (i) The interaction between $\mathrm{Mn}$ and Fe could increase the redox cycle ability, which is significantly vital to activate the reactant; (ii) the co-existence of active metal species with a different state could provide unsaturated and unbalanced chemical bonds, which enhances $\mathrm{NO}_{\mathrm{x}}$ removal [40]. $\mathrm{Mn}_{0.15} \mathrm{Fe}_{0.05} / \mathrm{FA}$ also has a high ratio of $\mathrm{O}_{\alpha} / \mathrm{O}_{\mathrm{t}}$, acting as an active site for $\mathrm{NH}_{3}$ adsorption to form. The high valence state metal $\left(\mathrm{Mn}^{4+}, \mathrm{Mn}^{3+}\right.$ and $\left.\mathrm{Fe}^{3+}\right)$ provides active sites for the reactant adsorption and activation and promotes the redox cycle combined with active oxygen species explains the excellent $\mathrm{NH}_{3}$-SCR activity of $\mathrm{Mn}_{0.15} \mathrm{Fe}_{0.05} / \mathrm{FA}$.

\subsubsection{Reducibility for the Low-Temperature Activity}

The existence of active species with different valence states within catalyst promotes the oxidation/reduction cycle proven by XPS results (Table 3). Thus, the redox property is an important index to evaluate the De- $\mathrm{NO}_{x}$ ability of the catalyst. The $\mathrm{H}_{2}$-TPR experiments were performed to examine the reducibility of different catalysts (Figure 2a,b). The $\mathrm{H}_{2}$-TPR curve of FA had a broad peak at around $400-650{ }^{\circ} \mathrm{C}$, attributed to the reduction of $\mathrm{FeO}_{x}$ inherently present in FA [41]. When metal oxides were added, the intensity of this peak increased gradually and shifted to a higher temperature. This result is caused by electronic transfer and healthy interaction between metal oxides and carrier, as indicated by XRD results that the metal oxide was doped into the $\mathrm{SiO}_{2}$ crystal structure. $\mathrm{Fe}_{0.10} / \mathrm{FA}$ produced two main peaks at around 419 and $572{ }^{\circ} \mathrm{C}$ that were associated with the reduction of $\mathrm{Fe}_{2} \mathrm{O}_{3}$ to $\mathrm{Fe}_{3} \mathrm{O}_{4}$, and $\mathrm{Fe}_{3} \mathrm{O}_{4}$ to $\mathrm{FeO}$ [41], respectively. Three peaks $\left((\alpha) 332,(\beta) 429\right.$, and $\left.(\delta) 488^{\circ} \mathrm{C}\right)$ appeared in $\mathrm{Mn}_{0.15} / \mathrm{FA}$ curve (Figure 2b), responsible for the reduction of the manganese oxide species [42]. All bimetal oxides containing catalysts produced peaks in three zones and were denoted as $\alpha, \beta$, and $\delta$, respectively. Based on a previous study [43], these zones were assigned to $\mathrm{MnO}_{2} \rightarrow \mathrm{Mn}_{2} \mathrm{O}_{3}(\alpha)$, $\mathrm{Mn}_{2} \mathrm{O}_{3} \rightarrow \mathrm{Mn}_{3} \mathrm{O}_{4}, \mathrm{Fe}_{2} \mathrm{O}_{3} \rightarrow \mathrm{Fe}_{3} \mathrm{O}_{4}(\beta), \mathrm{Mn}_{3} \mathrm{O}_{4} \rightarrow \mathrm{MnO}$, and $\mathrm{Fe}_{3} \mathrm{O}_{4} \rightarrow \mathrm{FeO}(\delta)$.

The primary objective of this work is to understand the reducibility of $\mathrm{NO}_{\mathrm{x}}$ by the catalysts at lower temperatures. Therefore, the first two zones were considered (Figure 2a,b). Furthermore, semi-quantitative $\mathrm{H}_{2}$-TPR analysis was conducted by calculating the peak area, and the results are given in Figure 3. For $\mathrm{Mn}_{\mathrm{x}} \mathrm{Fe}_{\mathrm{y}} / \mathrm{FA}$, the onset of reduction shifts to lower temperatures increasing the peak area of all peaks with the addition of $\mathrm{MnO}_{\mathrm{x}}$ or $\mathrm{FeO}_{\mathrm{x}}$. This phenomenon is caused by the interaction of $\mathrm{MnO}_{\mathrm{x}}, \mathrm{FeO}_{\mathrm{x}}$ and the carrier within the catalysts. Figure 3 shows that with the increase in $\mathrm{MnO}_{x}$ or $\mathrm{FeO}_{x}$ concentration, the peak area responsible for low-temperature reducibility $(\alpha)$ gradually increased. $\mathrm{Mn}_{0.15} \mathrm{Fe}_{0.10} / \mathrm{FA}$ and $\mathrm{Mn}_{0.15} \mathrm{Fe}_{0.05} / \mathrm{FA}$ have the best De- $\mathrm{NO}_{\mathrm{x}}$ activity within the series of the $\mathrm{Mn}_{x} \mathrm{Fe}_{0.10} / \mathrm{FA}$ and the $\mathrm{Mn}_{0.15} \mathrm{Fe}_{y} / \mathrm{FA}$, respectively. These two catalysts have medium reducibility. Therefore, the medium reducibility of $\mathrm{Mn}_{0.15} \mathrm{Fe}_{0.05} / \mathrm{FA}$ is an essential factor contributing to its outstanding De- $\mathrm{NO}_{x}$ activity.

Generally, the adsorption of gas reactants is the first step for a gas-solid reaction. Furthermore, SCR reactions are well established to be involved in both redox and adsorption active sites. To examine the $\mathrm{NH}_{3}$ and $\mathrm{NO}$ adsorption and activation ability of the catalyst, temperature program desorption, in-situ DRIFTs, and TG-MS techniques were used. 

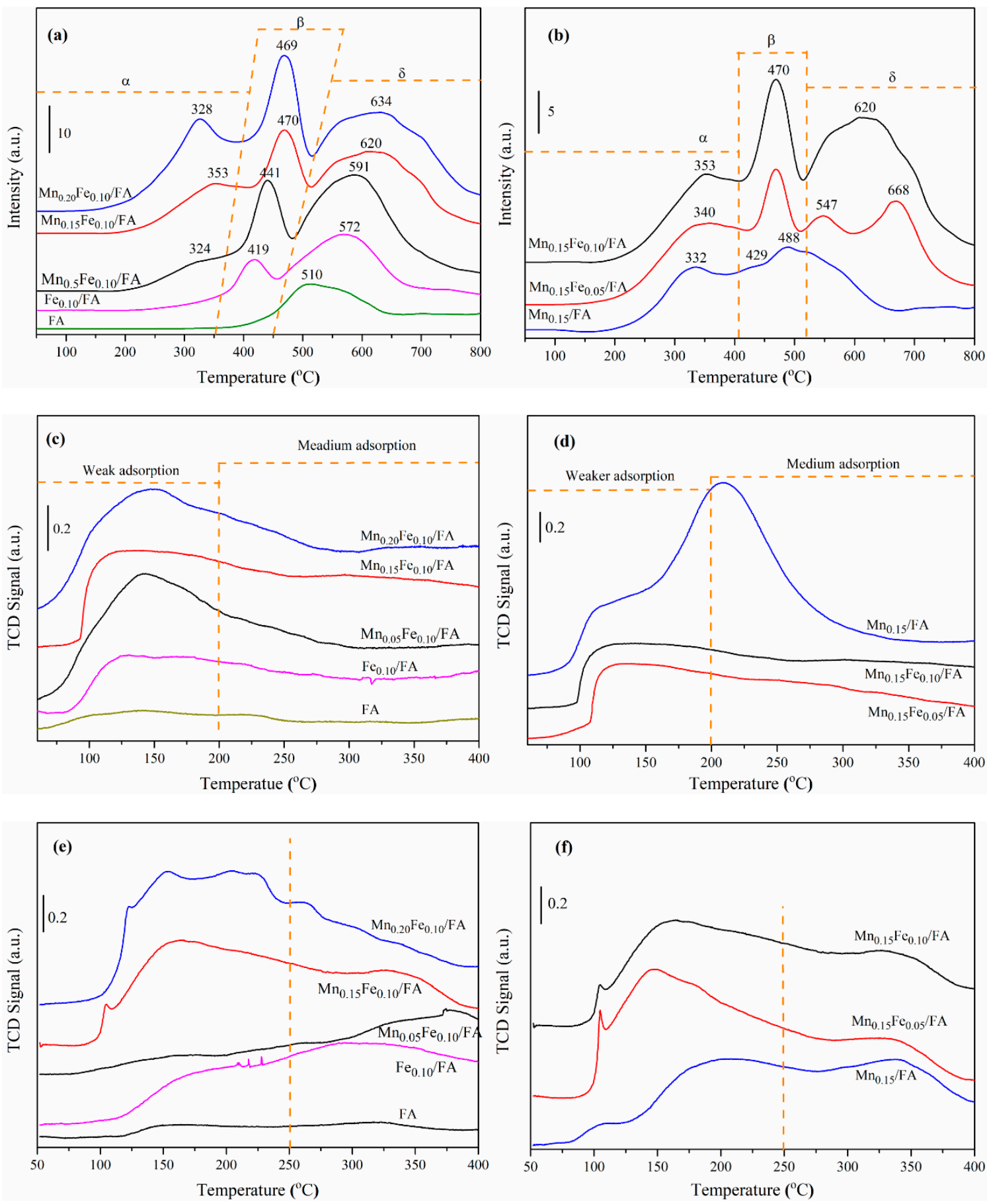

Figure 2. Profiles of $\mathrm{H}_{2}$-TPR (a), $\mathrm{NH}_{3}-\mathrm{TPD}(\mathbf{c})$, and NO-TPD (e) of $\mathrm{Mn}_{\mathrm{x}} \mathrm{Fe}_{0.10} / \mathrm{FA}(\mathrm{x}=0,0.05,0.15$ and 0.20); and $\mathrm{H}_{2}$-TPR (b), $\mathrm{NH}_{3}$-TPD (d), and NO-TPD profiles (f) of $\mathrm{Mn}_{0.15} \mathrm{Fe}_{\mathrm{y}} / \mathrm{FA}(\mathrm{y}=0,0.05$ and 0.10). 


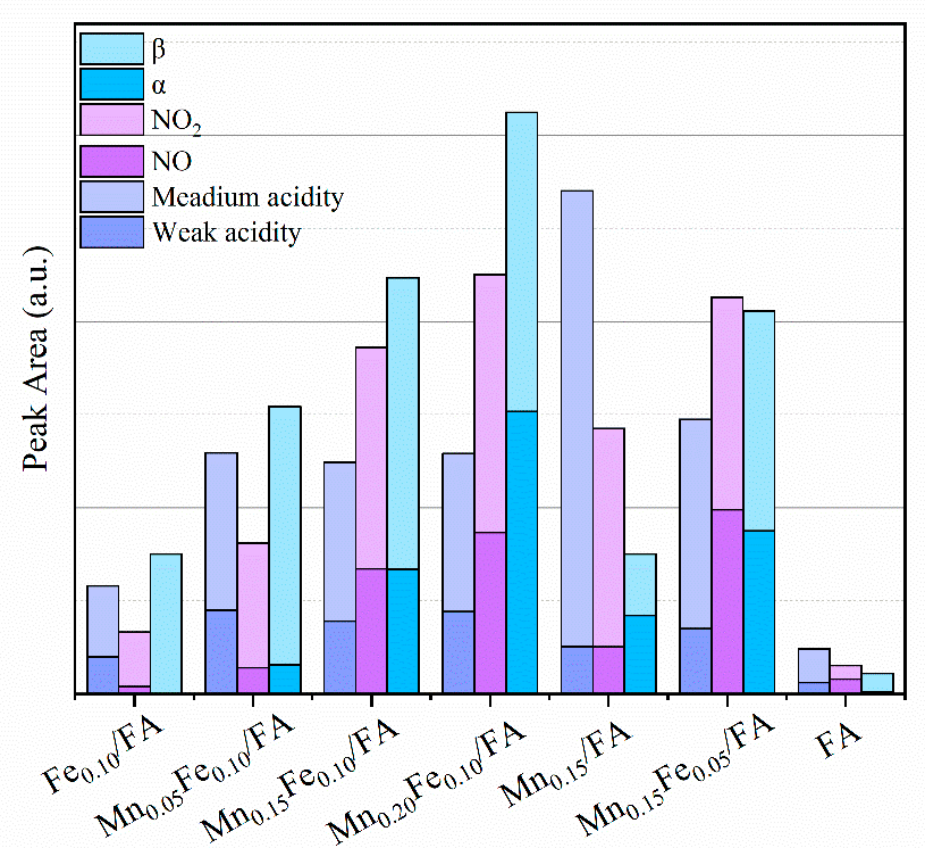

Figure 3. The peak area of $\mathrm{NO} / \mathrm{NH}_{3}-\mathrm{TPD}$ and $\mathrm{H}_{2}-\mathrm{TPR}$ on different catalysts.

\subsubsection{The Adsorption and Desorption Behavior of $\mathrm{NH}_{3} / \mathrm{NO}$}

The surface acid property of the catalyst is highly essential for $\mathrm{NH}_{3}$ adsorption on acidic sites. This is the first step of the $\mathrm{NH}_{3}-\mathrm{SCR}$ reaction. Thus, the strength and number of acidic sites were calculated by $\mathrm{NH}_{3}$-TPD technology. Figure 2c,d shows that all the $\mathrm{NH}_{3}$ desorption profiles showed one broad peak, including two desorption processes [44]: (1) $\mathrm{NH}_{3}$ desorption by weak acid sites $\left(100-200{ }^{\circ} \mathrm{C}\right)$ and $(2) \mathrm{NH}_{3}$ desorption peak $\left(200-400{ }^{\circ} \mathrm{C}\right)$ attributed to medium acid sites. The peak area allows for a semi-quantitative understanding of acid sites, and the results are shown in Figure 3. The carrier can provide a small number of acid sites because $\mathrm{FeO}_{\mathrm{x}}$ is inherently present in FA. For all catalysts, the total acidic sites of $\mathrm{Fe}_{0.10} / \mathrm{FA}$ is the lowest but is the highest for $\mathrm{Mn}_{0.15} / \mathrm{FA}$. However, bimetal-containing catalysts have similar total acidic sites. $\mathrm{Mn}_{0.15} \mathrm{Fe}_{0.05} / \mathrm{FA}$ has a slightly lower number of weak acidic sites, but it has the highest de- $\mathrm{NO}_{x}$ activity. It can be concluded from this result that mediocre surface acid property is just one of the factors influencing De- $\mathrm{NO}_{x}$ activity because excess and heavy adsorption of $\mathrm{NH}_{3}$ could have an inhibitory effect for De- $\mathrm{NO}_{x}$ efficiency [45].

Figure 2e,f shows the temperature-programmed desorption of $\mathrm{NO}_{\mathrm{x}}$ to test the adsorption capacity of NO. All samples present a broad desorption peak at the temperature range of $50-400{ }^{\circ} \mathrm{C}$. This temperature range can be divided into two segments: (1) At temperatures lower than $250{ }^{\circ} \mathrm{C}$ which is the desorption of physisorbed $\mathrm{NO}$ and disintegration of unstable nitrite species occurs, and (2) temperatures higher than $250{ }^{\circ} \mathrm{C}$ represents $\mathrm{NO}_{2}$ desorption due to the decomposition of stable thermal nitrates, such as bridged nitrate or bidentate bitrate that have high thermal stability [39]. The area of desorption peak could represent the semi-quantitative amount of $\mathrm{NO}_{x}$ species, and the results are shown in Figure 3. For all catalysts, the desorption amount of $\mathrm{NO}$ and $\mathrm{NO}_{2}$ increased with $\mathrm{MnO}_{\mathrm{x}}$ addition. In contrast, the desorption amount of $\mathrm{NO}$ increased and then decreased as the concentration of $\mathrm{FeO}_{\mathrm{x}}$ increased; the desorption amount of $\mathrm{NO}_{2}$ increased continuously. Therefore, it can be concluded that the balance between the adsorption of reactants $\left(\mathrm{NH}_{3}\right.$ and $\left.\mathrm{NO}_{\mathrm{x}}\right)$ and the redox ability of metal oxide plays a significant role in LTSCR.

To further investigate the decomposition characteristics of surface adsorbed species over $\mathrm{Mn}_{0.15} \mathrm{Fe}_{0.05} / \mathrm{FA}$, the pre-adsorbed catalyst with $\mathrm{NH}_{3}$ was studied with TG-MS (Figure S5). TG thermograms (Figure S5a) show a slight weight loss caused merely by the desorption of gas because the sample was calcinated at $500{ }^{\circ} \mathrm{C}$ for $3 \mathrm{~h}$. $\mathrm{Mn}_{0.15} \mathrm{Fe}_{0.05} / \mathrm{FA}$ can readily adsorb $\mathrm{NH}_{3}$ at $50{ }^{\circ} \mathrm{C}$, 
and then release $\mathrm{NH}_{3}$ species during the entire heating process, including $\mathrm{NH}_{3}, \mathrm{NH}_{2}, \mathrm{NH}_{4}{ }^{+}$, and $\mathrm{N}_{2} \mathrm{O}$. When the temperature increased, the $\mathrm{NH}_{3}$ was released. Because some of the $\mathrm{NH}_{3}$ was physically adsorbed and/or weakly chemically adsorbed on the Lewis acid sites, nevertheless, some ammonia species are chemically adsorbed on the active sites of $\mathrm{Mn}_{0.15} \mathrm{Fe}_{0.05} / \mathrm{FA}$ and can be activated by surface oxygen, such as surface oxygen, which can dehydrogenate $\mathrm{NH}_{3}$ and form intermediate surface species $\left(-\mathrm{NH}_{2}\right)$ [46]. The activated amide $\left(-\mathrm{NH}_{2}\right)$ groups have been a critical intermediate species because they can react with activated $\mathrm{NO}$ to form $\mathrm{NH}_{2} \mathrm{NO}$, which further decomposes to form $\mathrm{N}_{2}$ and $\mathrm{H}_{2} \mathrm{O}$, favoring the conversion of $\mathrm{NO}_{x}$ [47]. $\mathrm{NH}_{4}{ }^{+}$was formed by chemically adsorbed $\mathrm{NH}_{3}$ on the Brønsted acid sites. The results also showed that the formation of $\mathrm{N}_{2} \mathrm{O}$ due to the side reaction $\left(4 \mathrm{NH}_{3}+4 \mathrm{O}_{2} \rightarrow 2 \mathrm{~N}_{2} \mathrm{O}+6 \mathrm{H}_{2} \mathrm{O}\right)$. The formation of a large amount of $\mathrm{N}_{2} \mathrm{O}$ at $250{ }^{\circ} \mathrm{C}$ is the most important factor limiting the De- $\mathrm{NO}_{\mathrm{x}}$ capability of $\mathrm{Mn}_{0.15} \mathrm{Fe}_{0.05} / \mathrm{FA}$ at this temperature. All of the activated ammonia species act as an excellent intermediate during the SCR process [48].

Figure S6a shows the result of a mass change of pre-adsorbed $\mathrm{NO}$ on $\mathrm{Mn}_{0.15} \mathrm{Fe}_{0.05} / \mathrm{FA}$, and the desorbed species were recorded by TG-MS (Figure S6b-d), such as $\mathrm{H}_{2} \mathrm{O}, \mathrm{NO}$, and $\mathrm{NO}_{2}$. The TG thermogram (Figure S6a) shows two weight loss stages. The first stage at around $100{ }^{\circ} \mathrm{C}$ was assigned to dehydration and was recorded by MS (Figure S6b). The NO was released during all the weight loss stages, which the weakly adsorbed $\mathrm{NO}$ was released on the catalyst surface (Figure S6c). $\mathrm{NO}_{2}$ was disrobed in the second stage (Figure S6d), which was caused by gaseous NO reacting with the surface chemical oxygen to produce $\mathrm{NO}_{2}$ over $\mathrm{Fe}^{\mathrm{n}+}$ and $\mathrm{Mn}^{\mathrm{n}+}$ sites at a lower temperature $[25,49]$, and promotes the De- $\mathrm{NO}_{x}$ activity by "fast reaction". This reaction pathway is one of the reasons $\mathrm{Mn}_{0.15} \mathrm{Fe}_{0.05} / \mathrm{FA}$ has an excellent low-temperature activity.

\subsubsection{In-Situ DRIFT Analysis}

SCR catalytic performance is highly dependent on the adsorption capability of the catalyst. Gases such as $\mathrm{O}_{2}, \mathrm{NO}$, and $\mathrm{NH}_{3}$ are primary participants during SCR reaction. The adsorption capability of the catalyst was discussed in detail in the previous section. However, it is essential to understand the reactions occurring on the surface of the catalyst after the adsorption of primary participants. To understand the mechanism of the reactions on the surface of $\mathrm{Mn}_{0.15} \mathrm{Fe}_{0.05} / \mathrm{FA}$ catalyst by adsorption and reaction of reactants at active sites, the intermediates, and adsorbed species, four different experiments were conducted using the in-situ DRIFT at $150{ }^{\circ} \mathrm{C}$ : (1) $\mathrm{NH}_{3}$ adsorption; (2) $\mathrm{NO}+\mathrm{O}_{2}$ adsorption; (3) the reaction of $\mathrm{NO}+\mathrm{O}_{2}$ with pre-adsorbed $\mathrm{NH}_{3}$; and (4) the reaction of $\mathrm{NH}_{3}$ with pre-adsorbed $\mathrm{NO}+\mathrm{O}_{2}$.

The $\mathrm{NH}_{3}$ adsorption spectra are given in Figure 4a. Several peaks appeared immediately when the $\mathrm{NH}_{3}$ was introduced into the reaction cell after $1 \mathrm{~min}$, such as 1621, 1405, 1349, 1229, 966, and $929 \mathrm{~cm}^{-1}$. This phenomenon shows that $\mathrm{Mn}_{0.15} \mathrm{Fe}_{0.05} / \mathrm{FA}$ catalyst has a strong surface acidity, which can make $\mathrm{NH}_{3}$ readily adsorbed and then facilitate the De- $\mathrm{NO}_{x}$ reaction. During the 30 min adsorption of $\mathrm{NH}_{3}$, many adsorption peaks gradually increased in intensity. Studies show that these peaks can be divided into four groups: (1) The strong bands centered at 1621, 1270, 1227, and $1086 \mathrm{~cm}^{-1}$ were assigned to symmetric-asymmetric bending vibrations of the $\mathrm{N}-\mathrm{H}$ bonds within $\mathrm{NH}_{3}$ coordinately associated with Lewis acid sites [50]; (2) the 1694 and $1405 \mathrm{~cm}^{-1}$ weak bands were attributed to the $\mathrm{N}-\mathrm{H}$ bending vibration of $\mathrm{NH}_{4}{ }^{+}$species on Brønsted acid sites [51]; (3) the two bands at 1530 and $1349 \mathrm{~cm}^{-1}$ can represent $-\mathrm{NH}_{2}$ species [52], which were formed by the intermediate oxidation of adsorbed ammonia species. From the results of Figure S5, the formation of the activated amide $\left(-\mathrm{NH}_{2}\right)$ groups from dehydrogenation of $\mathrm{NH}_{3}$ is evident [46]; (4) the groups centered at 966 and $929 \mathrm{~cm}^{-1}$ were assigned to loosely adsorbed $\mathrm{NH}_{3}$ [44], indicating that $\mathrm{NH}_{3}$ can be readily adsorbed and activated on $\mathrm{Mn}_{0.15} \mathrm{Fe}_{0.05} / \mathrm{FA}$. 

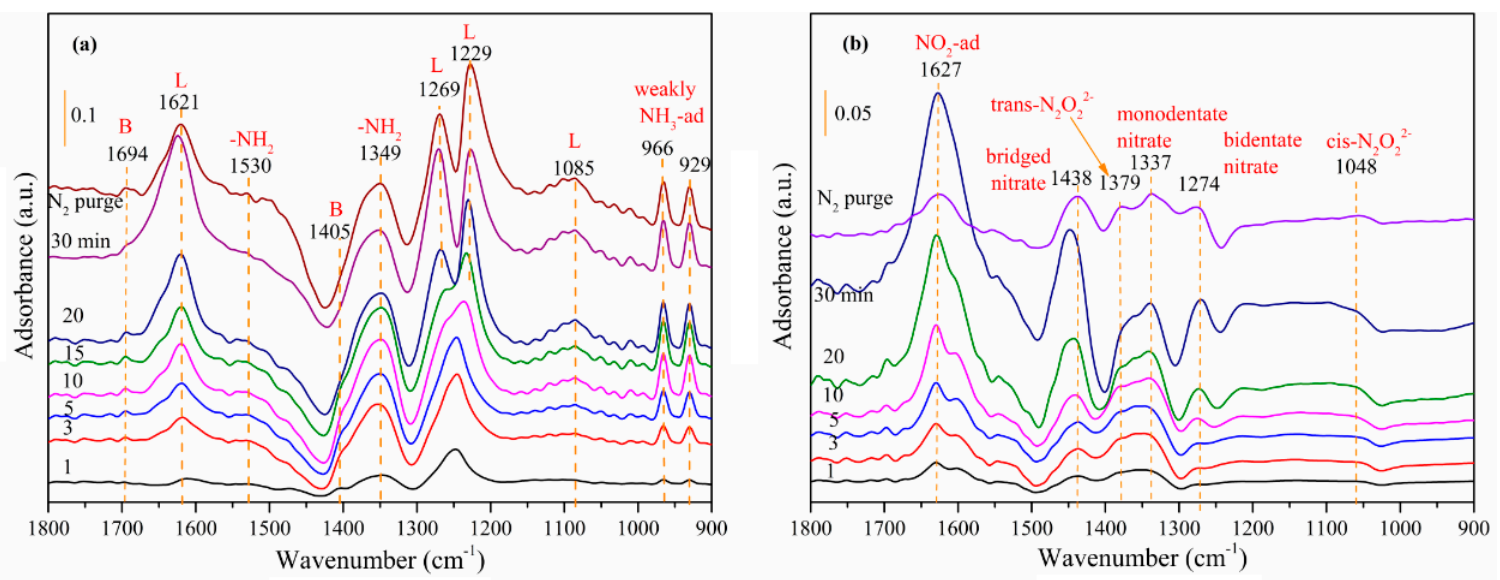

Figure 4. In-situ DRIFT spectra of $\mathrm{NH}_{3}$ adsorption over the $\mathrm{Mn}_{0.15} \mathrm{Fe}_{0.05} / \mathrm{FA}$ exposed to (a) $1000 \mathrm{ppm}$ $\mathrm{NH}_{3} / \mathrm{N}_{2}$ and (b) $1000 \mathrm{ppm} \mathrm{NO}+5 \% \mathrm{O}_{2}$ at $150{ }^{\circ} \mathrm{C}$.

Figure $4 \mathrm{~b}$ shows the in-situ DRIFT spectra of $\mathrm{NO}+\mathrm{O}_{2}$ adsorption on $\mathrm{Mn}_{0.15} \mathrm{Fe}_{0.05} / \mathrm{FA}$. A series of adsorption peaks $\left(1627,1438,1379,1337\right.$, and $\left.1274 \mathrm{~cm}^{-1}\right)$ appeared in the first minute when the mixed gas was added into the reaction cell. The reactant $\left(\mathrm{NO}+\mathrm{O}_{2}\right)$ can be readily adsorbed on the catalyst surface and then facilitate the De- $\mathrm{NO}_{x}$ reaction. The intensity of the adsorption peaks increased with time, indicating that the catalyst has a high adsorption ability of reactant. The high adsorption ability of the catalyst allows for an efficient SCR reaction, explaining the excellent catalytic performance of $\mathrm{Mn}_{0.15} \mathrm{Fe}_{0.05} / \mathrm{FA}$. The asymmetric stretching vibration of loosely adsorbed $\mathrm{NO}_{2}$ was shown at $1627 \mathrm{~cm}^{-1}$ [53], formed as a result of $\mathrm{NO}$ reacting with $\mathrm{O}_{2}$ and/or the reaction of $\mathrm{NO}$ and chemisorbed oxygen [54]. The bands at 1438, 1337, and $1274 \mathrm{~cm}^{-1}$ were assigned to bridged nitrate, monodentate nitrate, and bidentate nitrate [54]. The bands at 1379 and $1048 \mathrm{~cm}^{-1}$ are responsible for trans- and cis- $\mathrm{N}_{2} \mathrm{O}_{2}$ [47]. When the pre-adsorbed $\left(\mathrm{NO}+\mathrm{O}_{2}\right)$ catalyst was purged by nitrogen, most of the peaks appeared weaker than before, indicating that the adsorbed $\mathrm{NO}_{\mathrm{x}}$ species are easily formed and decomposed, facilitating the cycle of nitro compounds, making a good foundation on the reaction.

The in-situ DRIFT spectra of the reaction between $\mathrm{NO}+\mathrm{O}_{2}$ and pre-adsorbed $\mathrm{NH}_{3}$ at different time intervals are shown in Figure 5a. As mentioned above in (Figure 4a), after the adsorption of $\mathrm{NH}_{3}$, the catalyst exhibits Lewis (L) acid sites related bands $\left(1621,1269,1227\right.$, and $\left.1086 \mathrm{~cm}^{-1}\right)$, Brønsted (B) acid sites (1694 and $\left.1405 \mathrm{~cm}^{-1}\right)$, loosely adsorbed $\mathrm{NH}_{3}\left(966\right.$ and $\left.929 \mathrm{~cm}^{-1}\right)$ and $-\mathrm{NH}_{2}$ (1530 and $1349 \mathrm{~cm}^{-1}$ ). When $\mathrm{NO}+\mathrm{O}_{2}$ mixture was introduced, both the acid sites ( $\mathrm{L}$ and $\mathrm{B}$ ) and active intermediate bands decreased immediately, and many new nitrate species bands appeared and increased gradually during the reaction process. These changes indicated that almost all of the adsorbed $\mathrm{NH}_{3}$ species could react with $\mathrm{NO}+\mathrm{O}_{2}$ to form new species, such as bridged nitrate $\left(1616 \mathrm{~cm}^{-1}\right)$, bidentate nitrate $\left(1696,1568,1270\right.$, and $\left.1102 \mathrm{~cm}^{-1}\right)$ [55], monodentate nitrate $\left(1355 \mathrm{~cm}^{-1}\right)$, trans- and cis- $\mathrm{N}_{2} \mathrm{O}_{2}{ }^{2-}\left(1403\right.$ and $\left.1031 \mathrm{~cm}^{-1}\right)$, unstable nitrate species $\left(1227 \mathrm{~cm}^{-1}\right)$ [56]. Over time, these peaks became more pronounced. However, the intensity of loosely adsorbed $\mathrm{NH}_{3}$ (967 and $929 \mathrm{~cm}^{-1}$ ) slightly decreased, which indicates that it reacted with $\mathrm{NO}_{\mathrm{x}}$ species and formed a small number of nitrate species.

The other transient reaction experiment was also carried out. In this reaction, $\mathrm{NO}+\mathrm{O}_{2}$ was co-adsorbed at first, and then $\mathrm{NH}_{3}$ was added. The results are given in Figure 5b. As observed, before the addition of $\mathrm{NH}_{3}$, the bands of $\mathrm{NO}_{\mathrm{x}}$ species $\left(\mathrm{NO}_{2}\left(1627 \mathrm{~cm}^{-1}\right)\right.$, bridged nitrate $\left(1438 \mathrm{~cm}^{-1}\right)$, monodentate nitrate $\left(1337 \mathrm{~cm}^{-1}\right)$, bidentate nitrate $\left(1274 \mathrm{~cm}^{-1}\right)$, trans- and cis- $\mathrm{N}_{2} \mathrm{O}_{2}{ }^{2-}(1379$ and $1048 \mathrm{~cm}^{-1}$ ) were identical to the previous experiment shown in Figure $5 \mathrm{~b}$. After the addition of $\mathrm{NH}_{3}$, the following phenomena were observed: (1) the intensity of the peak assigned to the adsorbed $\mathrm{NO}_{2}$ (NO oxidation by active oxygen-species) and nitrate species decreased immediately; (2) some of the $\mathrm{NH}_{3}$ species $\left(\mathrm{NH}_{3}\right.$ coordinate to Lewis acid sites $\left(1085 \mathrm{~cm}^{-1}\right)$, trans- $\mathrm{N}_{2} \mathrm{O}_{2}{ }^{2-}\left(1379 \mathrm{~cm}^{-1}\right)$ and loosely 
adsorbed $\mathrm{NH}_{3}$ (967 and $\left.929 \mathrm{~cm}^{-1}\right)$ ) appeared, and the intensity increased with time; (3) formation of new nitrate species such as bridged nitrate $\left(1617,1458 \mathrm{~cm}^{-1}\right)$, bidentate nitrate $\left(1568\right.$ and $\left.1538 \mathrm{~cm}^{-1}\right)$, monodentate nitrate $\left(1337 \mathrm{~cm}^{-1}\right)$, unstable nitrate species $\left(1242 \mathrm{~cm}^{-1}\right)$ and trans- $\mathrm{N}_{2} \mathrm{O}_{2}{ }^{2-}\left(1379 \mathrm{~cm}^{-1}\right)$. Among these, the bands of monodentate nitrates $\left(1337 \mathrm{~cm}^{-1}\right)$ were always present and increased with time, suggesting that the monodentate nitrates did not react with ammonia species, and the other $\mathrm{NO}_{\mathrm{x}}$ species (bidentate nitrate and trans- $\mathrm{N}_{2} \mathrm{O}_{2}{ }^{2-}$ ) reacted with $\mathrm{NH}_{3}$ to form monodentate nitrates. However, the bands of weakly adsorbed $\mathrm{NO}_{2}\left(1627 \mathrm{~cm}^{-1}\right)$, bidentate nitrate $\left(1274 \mathrm{~cm}^{-1}\right)$ and cis- $\mathrm{N}_{2} \mathrm{O}_{2}{ }^{2-}\left(1048 \mathrm{~cm}^{-1}\right)$ quickly vanished, indicating that they reacted with the introduced $\mathrm{NH}_{3}$.
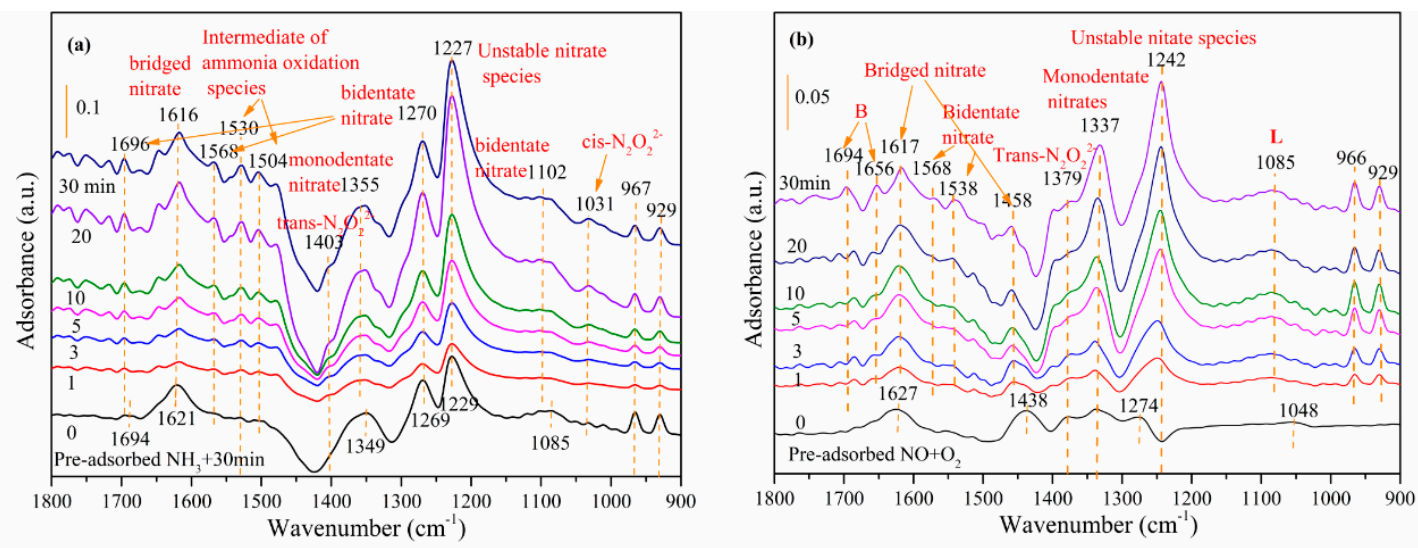

Figure 5. In-situ DRIFT spectra of (a) $\mathrm{NO}+\mathrm{O}_{2}$ reacted with pre-adsorbed $\mathrm{NH}_{3}$, and (b) $\mathrm{NH}_{3}$ reacted with pre-adsorbed $\mathrm{NO}+\mathrm{O}_{2}$ over the $\mathrm{Mn}_{0.15} \mathrm{Fe}_{0.05} / \mathrm{FA}$ at $150{ }^{\circ} \mathrm{C}$.

\subsubsection{Mechanisms and Reaction Pathways}

$\mathrm{NH}_{3} / \mathrm{NO}-\mathrm{TPD}$ and pre-adsorbed $\mathrm{NH}_{3} / \mathrm{NO}-\mathrm{TG}-\mathrm{MS}$ results showed that $\mathrm{Mn}_{0.15} \mathrm{Fe}_{0.05} / \mathrm{FA}$ could quickly adsorb and activate the reactants at $150{ }^{\circ} \mathrm{C}$, which is promoted by the addition of a proper amount of metal ion providing the optimum amount of acid and active sites. The primary function of active sites is to adsorb and activate the reactants $\left(\mathrm{NH}_{3}, \mathrm{NO}_{\mathrm{x}}\right.$, and $\left.\mathrm{O}_{2}\right)$ to produce the $\mathrm{NH}_{3}$ species and nitrates. Moreover, in-situ DRIFTs analysis showed that $\mathrm{NH}_{3}$ could be easily oxidized to $\mathrm{NH}_{2}$ as an active intermediate were adsorbed on Lewis and Brønsted acid sites. With the introduction of $\mathrm{NO}+\mathrm{O}_{2}$, most of the absorbed ammonia species decreased, and new species were formed (Figure 5a). The highly reactive $\mathrm{NH}_{2}$ species reacted with $\mathrm{NO}_{\mathrm{x}}\left(\mathrm{NO}, \mathrm{NO}_{2}\right)$ to form $\mathrm{NH}_{2} \mathrm{NO}$ or $\mathrm{NH}_{2} \mathrm{NO}_{2}$, which rapidly discomposed into $\mathrm{N}_{2}$ and $\mathrm{H}_{2} \mathrm{O}$ [57]. As given in Figure $5 \mathrm{~b}$, the adsorbed $\mathrm{NO}_{2}$ or nitrates species reacts with adsorbed ammonia species when the $\mathrm{NH}_{3}$ was confirmed to follow the Langmuir-Hishelwood (L-H) mechanism.

According to several previous studies [58] combined with our findings, the L-H reaction pathway mainly occurs during the reaction as follows: (M denotes Fe and/or elemental Mn)

$$
\begin{gathered}
\mathrm{NH}_{3}(\mathrm{~g}) \rightarrow \mathrm{NH}_{3(\mathrm{ad})} \\
\mathrm{NH}_{3}(\mathrm{~g}) \rightarrow \mathrm{NH}_{2(\mathrm{ad})} \\
\mathrm{O}_{2}(\mathrm{~g}) \rightarrow 2 \mathrm{O}^{*} \\
\mathrm{NO}(\mathrm{g})+\mathrm{O}^{*} \rightarrow \mathrm{NO}_{2}(\mathrm{ad}) \\
\mathrm{NH}_{2}(\mathrm{ad})+\mathrm{NO}_{2}(\mathrm{ad}) \rightarrow \mathrm{NH}_{2} \mathrm{NO}_{2} \\
\mathrm{NH}_{2} \mathrm{NO}_{2} \rightarrow \mathrm{N}_{2}+\mathrm{H}_{2} \mathrm{O} \\
\mathrm{NH}_{2}(\mathrm{ad})+\mathrm{NO}_{(\mathrm{ad})} \rightarrow \mathrm{NH}_{2} \mathrm{NO}
\end{gathered}
$$




$$
\begin{gathered}
\mathrm{NH}_{2} \mathrm{NO} \rightarrow \mathrm{N}_{2}+\mathrm{H}_{2} \mathrm{O} \\
\mathrm{NO}_{2(\text { ad })}+\mathrm{O}^{*} \rightarrow \mathrm{NO}_{3}^{-} \\
\mathrm{NH}_{3}(\text { ad })+\mathrm{NO}_{3}^{-} \rightarrow \mathrm{N}_{2}+\mathrm{H}_{2} \mathrm{O}
\end{gathered}
$$

\section{Materials and Methodology}

\subsection{Preparation of Catalysts}

The catalyst samples were obtained by a co-impregnation technique using FA as the catalyst carrier. The FA used in this study was obtained from Fushun Zhong Ji Thermal Power Plant, Fushun, China. The elemental composition of FA consists of $\mathrm{SiO}_{2}(47.42 \%), \mathrm{Al}_{2} \mathrm{O}_{3}\left(24.25\right.$ wt.\%), $\mathrm{Fe}_{2} \mathrm{O}_{3}$ (7.91 wt.\%), $\mathrm{CaO}\left(3.44\right.$ wt.\%), $\mathrm{TiO}_{2}\left(1.89\right.$ wt.\%), $\mathrm{K}_{2} \mathrm{O}(1.74 \mathrm{wt.} \%), \mathrm{MgO}(1.12 \mathrm{wt.} \%)$, and others (measured by $\mathrm{X}$-ray fluorescence analysis). The FA was dried at $105^{\circ} \mathrm{C}$ for $12 \mathrm{~h}$ before all experiments. $\mathrm{Fe}\left(\mathrm{NO}_{3}\right)_{3} \cdot 9 \mathrm{H}_{2} \mathrm{O}$ $(99.99 \%, \mathrm{AR})$ and $\mathrm{Mn}\left(\mathrm{NO}_{3}\right)_{3} \cdot 4 \mathrm{H}_{2} \mathrm{O}(99.99 \%, \mathrm{AR})$ were used as precursors, and they were obtained from Sinopharm Chemical Reagent Co. Ltd, (Shanghai, China).

The catalysts were prepared in the following order: Firstly, a different concentration of manganese nitrate and iron nitrate was dissolved in de-ionized water. Secondly, $4 \mathrm{~g}$ of FA was added to the solution with the ultrasonication of the slurry for $1 \mathrm{~h}$ at $80^{\circ} \mathrm{C}$. Thirdly, aqueous ammonia solution (75\%) (Sinopharm Chemical Reagent Co. Ltd, (Shanghai, China)) was added drop by drop until a basic mixture was obtained ( $\mathrm{pH} \sim 10)$. Then, the mixture was dried at $105^{\circ} \mathrm{C}$ for $10 \mathrm{~h}$ prior to the calcination process. The catalyst sample was calcined in an electric oven at $500^{\circ} \mathrm{C}$ at $10{ }^{\circ} \mathrm{C} / \mathrm{min}$ for three hours. After that, the dried product with a particle size range of $250-400 \mu \mathrm{m}$ was used for further analysis. The obtained samples were named $\mathrm{Mn}_{\mathrm{x}} \mathrm{Fe}_{\mathrm{y}} / \mathrm{FA}$, in which the value of ' $\mathrm{x}$ ' ranges from 0 to 0.2 , and the value of ' $y$ ' ranges from 0 to 0.10 , representing the weight ratios of manganese/FA and iron/FA, respectively. For comparison purposes, fly ash was treated via the same preparation method, named FA.

\subsection{Low-Temperature SCR Experiments}

The $\mathrm{NH}_{3}$-SCR activity was conducted in a fixed-bed quartz reactor $(20 \mathrm{~mm}$ i.d.). The experimental setup (Figure 6) consists of three parts: the flue gas simulation system, reaction system, and tail gas test system. The reaction was conducted under a mixture of gases (with $(\mathrm{NO})$ and $\left(\mathrm{NH}_{3}\right)$ of $0.1 \mathrm{vol} . \%$, and $\left(\mathrm{O}_{2}\right)$ of $\left.5 \mathrm{vol} . \%\right)$, and $\mathrm{N}_{2}\left(1200 \mathrm{~mL} \cdot \mathrm{min}^{-1}\right)$ was used as a balance gas, equivalent to a GHSV of $50,000 \mathrm{~h}^{-1}$. Activity tests were carried out each $50{ }^{\circ} \mathrm{C}$ in the range of 100 to $300{ }^{\circ} \mathrm{C}$, which was heated using a tubular furnace. The concentration of $\mathrm{NO}_{x}\left(\mathrm{NO}\right.$ and $\left.\mathrm{NO}_{2}\right)$ was measured by a flue gas analyzer (MRU 5, Germany) and were recorded at each test temperature after stabilization for half an hour.

$\mathrm{NO}_{x}$ conversion is calculated by Equation (14).

$$
\mathrm{NO}_{\mathrm{x}} \text { Conversion }(\%)=\frac{\mathrm{C}_{\mathrm{NO}_{\mathrm{x}} \text { in }}-\mathrm{C}_{\mathrm{NO}_{\mathrm{x}} \text { out }}}{\mathrm{C}_{\mathrm{NO}_{\mathrm{x}}} \text { in }} \times 100 \%
$$

where $\mathrm{C}_{\mathrm{NO}}$ in and $\mathrm{C}_{\mathrm{NO}_{\mathrm{x}} \text { out }}$ are the $\mathrm{NO}_{\mathrm{x}}$ concentration at the reactor inlet and outlet, respectively.

\subsection{Characterization of Catalyst Samples}

The morphology of the materials was analyzed by scanning electron microscopy (SEM, Zeiss SIGMA HD, (Oberkochen, Germany)). The physical properties of the catalysts were checked by an $\mathrm{N}_{2}$-physisorption analyzer using Kubo X1000 (Beijing Builder Electronic Technology Co. LTD, (Beijing, China)). The X-ray diffraction patterns were determined (Ultima IV, Rigaku, (Tokyo, Japan)) using a $\mathrm{Cu} \mathrm{K}{ }^{\alpha}$ radiation to obtain the crystal phase structure. The composition of Fe and $\mathrm{Mn}$ within the catalysts were determined by the inductively coupled plasma atomic emission spectroscopy (ICP-AES) technique, using Horiba Ultima 2 (Horiba, LTD, (Kyoto, Japan)). A high-performance 
electron spectrometer (ESCALAB 250, Thermo Fisher Scientific, Inc., (Waltham, MA, USA)) was used to carry out the X-ray photoelectron spectroscopy (XPS) experiments with monochromatic $\mathrm{Al} \mathrm{K \alpha}$ radiation $(1486.8 \mathrm{eV}, 150 \mathrm{w})$ and the $\mathrm{C} 1 \mathrm{~s}(284.8 \mathrm{eV})$ as a reference to calculate the binding energies to investigate the elemental state of catalyst surfaces. The XPS peak 4.1 software was used for curve fitting (Shirley background, Gaussian-Lorentzian ratio fixed to 80/20).

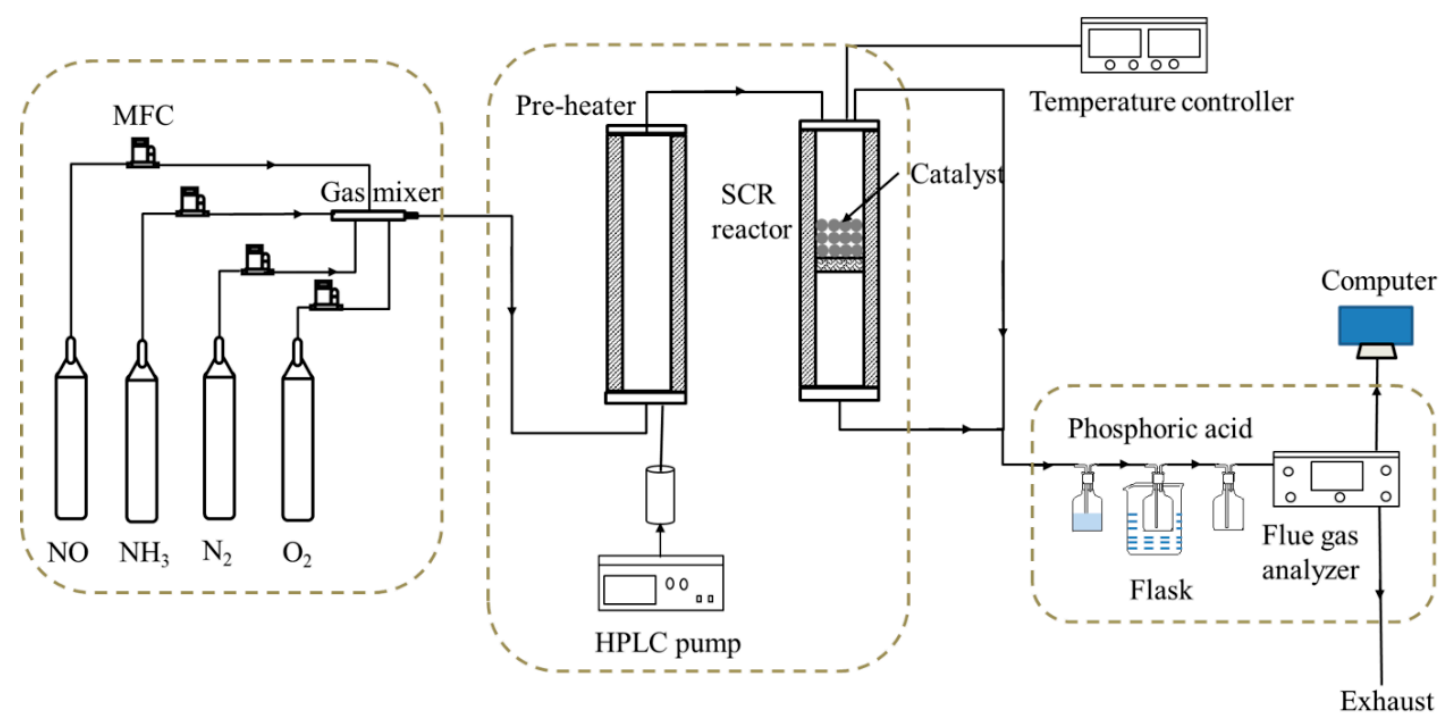

Figure 6. The schematic diagram of the experimental setup for $\mathrm{De}-\mathrm{NO}_{\mathrm{x}}$ experiments.

The temperature-programmed desorption $\left(\mathrm{NH}_{3} / \mathrm{NO}-\mathrm{TPD}\right)$ and the temperature program reduction ( $\mathrm{H}_{2}$-TPR) experiments were conducted on the chemisorption analyzer with a TCD (PCA-1200, Beijing Builder Electronic Technology Co. LTD (Beijing, China)). Before each TPD experiment, all the samples were de-gassed in $\mathrm{He}\left(30 \mathrm{~mL} \cdot \mathrm{min}^{-1}\right)$ at $300{ }^{\circ} \mathrm{C}$ for $1 \mathrm{~h}$. The absorption segment was carried out in 10 vol. $\% \mathrm{NH}_{3} / \mathrm{He}$ (or $10 \mathrm{vol} . \% \mathrm{NO} / \mathrm{He}$ ) at $50{ }^{\circ} \mathrm{C}$ for $1 \mathrm{~h}$, and then the samples were purged by $\mathrm{He}$ for half an hour to reach a stable baseline. Finally, the temperature of the catalyst was increased to $400{ }^{\circ} \mathrm{C}\left(10^{\circ} \mathrm{C} \cdot \mathrm{min}^{-1}\right)$. However, the $\mathrm{H}_{2}$-TPR experiment started with a stable baseline by TCD under $\mathrm{H}_{2}$ flow (10 vol.\% $\left.\mathrm{H}_{2} / \mathrm{Ar}\right)$. Then, the TCD test was carried out during the heating of the catalyst to $800{ }^{\circ} \mathrm{C}\left(10^{\circ} \mathrm{C} \cdot \mathrm{min}^{-1}\right)$. Desorption and decomposition properties of the surface species of the catalyst were tested by a simultaneous thermal analyzer (STA 8000, PerkinElmer, Inc., (Waltham, MA, USA)) attached with a Hiden HPR20 mass spectrometer (MS) (Hiden Analytical, Inc., (Peterborough, $\mathrm{NH}, \mathrm{USA})$ ). Before each run, the sample was first adsorbed with $\mathrm{NO}$ or $\mathrm{NH}_{3}$, similar to the TPD process. Then, the temperature was ramped at a similar heating rate $\left(10^{\circ} \mathrm{C} \cdot \mathrm{min}^{-1}\right)$ under helium. The in-situ DRIFT spectroscopy was conducted on FTIR spectrometer (Nicolet IS50, Thermo Fisher Scientific, Inc., (Waltham, MA, USA)) equipped with a ZnSe reaction cell. The sample was first de-gassed at $300{ }^{\circ} \mathrm{C}$ for $1 \mathrm{~h}$ under nitrogen gas $\left(100 \mathrm{~mL} \cdot \mathrm{min}^{-1}\right)$ to remove any adsorbed species (e.g., air or vapor). During the experiment, the background spectrum was obtained at the corresponding temperature, and then the reactant gas $\left(\left[\mathrm{NH}_{3}\right]=1000 \mathrm{ppm}\right.$ or $[\mathrm{NO}]=1000 \mathrm{ppm}$ combine with $\left.\left[\mathrm{O}_{2}\right]=5 \mathrm{vol} . \%\right)$ was introduced.

\section{Conclusions}

The $\mathrm{Mn}_{0.15} \mathrm{Fe}_{0.05} / \mathrm{FA}$ catalysts supported on coal fly ash had an excellent LTSCR catalytic performance in the temperature window between $130{ }^{\circ} \mathrm{C}$ and $300^{\circ} \mathrm{C}$. The optimum SCR activity in this study was obtained in the catalyst containing 0.05 and 0.15 weight ratios of $\mathrm{Mn} / \mathrm{FA}$ and $\mathrm{Fe} / \mathrm{FA}$, respectively.

The great De- $\mathrm{NO}_{\mathrm{x}}$ activity of $\mathrm{Mn}_{0.15} \mathrm{Fe}_{0.05} / \mathrm{FA}$ was attributed to the following favorable properties: (1) The doped $\mathrm{FeO}_{x}$ can promote the production of more high valence states of $\mathrm{Mn}$ that enriched these 
$\mathrm{Mn}^{4+}$ species on the surface; (2) the interaction between the doped species $\left(\mathrm{MnO}_{\mathrm{x}}, \mathrm{FeO}_{\mathrm{x}}\right)$ and $\mathrm{FA}$ provides an abundant amount of active sites, promoting adsorption and activation of reactants; (3) the proper amount of acid property, reactant adsorption, and redox ability together are the primary factors contributing to the excellent LTSCR efficiency for Mn0.15Fe0.05/FA; (4) the synthesis of $\mathrm{Mn}_{0.15} \mathrm{Fe}_{0.05} / \mathrm{FA}$ provides a potential high value-added application of coal fly ash, not only to decrease $\mathrm{NO}_{\mathrm{x}}$ emissions but also to promote the development of cost-effective low-temperature $\mathrm{NH}_{3}$-SCR catalysts.

The presence of $\mathrm{SO}_{2}$ (even in a small amount) may strongly impact the performance of low-temperature SCR systems. Future research should be focused on improving the $\mathrm{SO}_{2}$ poisoning resistance of the catalysts by introducing additives and changing the structure of catalysts.

Supplementary Materials: The following are available online at http://www.mdpi.com/2073-4344/10/12/1399/s1, Figure S1: The SEM images of (a) FA, (b) $\mathrm{Fe}_{0.10} / \mathrm{FA}$, (c) $\mathrm{Mn}_{0.05} \mathrm{Fe}_{0.10} / \mathrm{FA}$, (d) $\mathrm{Mn}_{0.15} \mathrm{Fe}_{0.10} / \mathrm{FA}$, (e) $\mathrm{Mn}_{0.20} \mathrm{Fe}_{0.10} / \mathrm{FA}$, (f) $\mathrm{Mn}_{0.15} / \mathrm{FA}$ and $(\mathrm{g}) \mathrm{Mn}_{0.15} \mathrm{Fe}_{0.05} / \mathrm{FA}$; Figure S2: $\mathrm{N}_{2}$ adsorption-desorption isotherms and pore size distribution

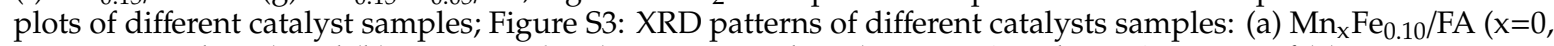
$0.05,0.15$, and 0.20 ) and (b) $\mathrm{Mn}_{0.15} \mathrm{Fe}_{\mathrm{y}} / \mathrm{FA}(\mathrm{y}=0,0.05$, and 0.10); Figure S4: The XPS spectra of (a) Mn 2p spectra, (b) Fe 3p spectra, (c) O 1s over different catalysts, respectively; Figure S5: TG and DTG curves (a) and mass spectra of nitrogen-containing species (b)-(e) during the heating of the $\mathrm{Mn}_{0.15} \mathrm{Fe}_{0.05} / \mathrm{FA}$ catalyst that pre-adsorbed $\mathrm{NH}_{3}$; Figure S6: TG and DTG curves (a) and mass spectra of nitrogen-containing species (b)-(e) during the heating of the $\mathrm{Mn}_{0.15} \mathrm{Fe}_{0.05} / \mathrm{FA}$ catalyst that pre-adsorbed NO; Table S1: The results of XPS analyses of the catalysts.

Author Contributions: Data curation, X.D., J.D., and Y.Z.; writing-original draft, X.D.; investigation, X.D. and J.D.; Formal analysis, J.D. and Y.Z.; methodology, X.D. and S.K.R.; writing-review and editing, S.K.R.; project administration, J.Y.; supervision, J.Y. All authors have read and agreed to the published version of the manuscript.

Funding: The work was carried out within a bilateral collaboration between the University of Science and Technology Liaoning and the University of Newcastle, which is financially supported by Key R\&D Funding Scheme of Liaoning Province, China, grant no. 2017308008, Liaoning High-level Innovation Team Overseas Training Project, China, grant no. 2018LNGXGJWPY-YB010, and ARC Linkage Project, Australia, grant no. LP160100540.

Acknowledgments: The authors gratefully acknowledge the financial support of the Key R\&D Funding Scheme of Liaoning Province (2017308008), Liaoning High-level Innovation Team Overseas Training Project (2018LNGXGJWPY-YB010), and ARC Linkage Project (LP160100540). The Talents Training Program of the University of Science and Technology Liaoning (2019RC12) is also acknowledged. The authors are grateful to Joy Omoriyekomwan and Joseph Appiah for assisting with manuscript writing.

Conflicts of Interest: The authors declare no conflict of interest.

\section{References}

1. Yao, Z.T.; Xia, M.S.; Sarker, P.K.; Chen, T. A review of the alumina recovery from coal fly ash, with a focus in China. Fuel 2014, 120, 74-85. [CrossRef]

2. Gao, E.; Sun, G.; Zhang, W.; Bernards, M.T.; He, Y.; Pan, H.; Shi, Y. Surface lattice oxygen activation via $\mathrm{Zr}^{4+}$ cations substituting on $\mathrm{A}^{2+}$ sites of $\mathrm{MnCr}_{2} \mathrm{O}_{4}$ forming $\mathrm{Zr}_{\mathrm{x}} \mathrm{Mn}_{1-\mathrm{x}} \mathrm{Cr}_{2} \mathrm{O}_{4}$ catalysts for enhanced $\mathrm{NH}_{3}-\mathrm{SCR}$ performance. Chem. Eng. J. 2020, 380. [CrossRef]

3. Tong, Y.; Li, Y.; Li, Z.; Wang, P.; Zhang, Z.; Zhao, X.; Yuan, F.; Zhu, Y. Influence of Sm on the low temperature $\mathrm{NH}_{3}$-SCR of $\mathrm{NO}$ activity and $\mathrm{H}_{2} \mathrm{O} / \mathrm{SO}_{2}$ resistance over the $\mathrm{Sm}_{\mathrm{a}} \mathrm{MnNi}_{2} \mathrm{Ti}_{7} \mathrm{O}_{\mathrm{x}}(\mathrm{a}=0.1,0.2,0.3,0.4)$ catalysts. Appl. Catal. A Gen. 2020, 590, 117333. [CrossRef]

4. Chen, P.J.; Yang, R.T. Role of $\mathrm{WO}_{3}$ in mixed $\mathrm{V}_{2} \mathrm{O}_{5}-\mathrm{WO}_{3} / \mathrm{TiO}_{2}$ catalysts for selective catalytic reduction of nitric oxide with ammonia. Appl. Catal. A Gen. 1992, 80, 135-148. [CrossRef]

5. Zhang, W.; Shi, X.; Shan, Y.; Liu, J.; Xu, G.; Du, J.; Yan, Z.; Yun, Y.; He, H. Promotion effect of cerium doping on iron-titanium composite oxide catalysts for selective catalytic reduction of $\mathrm{NO}_{\mathbf{x}}$ with $\mathrm{NH}_{3}$. Catal. Sci. Technol. 2020, 10, 648-657. [CrossRef]

6. Wu, S.; Zhang, L.; Wang, X.; Zou, W.; Cao, Y.; Sun, J.; Tang, C.; Gao, F.; Deng, Y.; Dong, L. Synthesis, characterization and catalytic performance of $\mathrm{FeMnTiO}_{\mathrm{x}}$ mixed oxides catalyst prepared by a CTAB-assisted process for mid-low temperature $\mathrm{NH}_{3}$-SCR. Appl. Catal. A Gen. 2015, 505, 235-242. [CrossRef]

7. Zha, K.; Zha, K.; Feng, C.; Han, L.; Li, H.; Yan, T.; Kuboon, S.; Shi, L.; Zhang, D. Promotional effects of Fe on manganese oxide octahedral molecular sieves for alkali-resistant catalytic reduction of $\mathrm{NO}_{\mathrm{x}}$ : XAFS and in situ DRIFTs study. Chem. Eng. J. 2020, 381, 122764. [CrossRef] 
8. Yao, H.; Yao, H.; Cai, S.; Yang, B.; Han, L.; Wang, P.; Li, H.; Yan, T.; Shi, L.; Zhang, D. In-situ decorated MOFs-derived Mn-Fe oxides on Fe mesh as novel monolith catalysts for $\mathrm{NO}_{\mathrm{x}}$ reduction. New J. Chem. 2020, 44, 2357-2366. [CrossRef]

9. Yang, J.; Ren, S.; Zhang, T.; Su, Z.; Long, H.; Kong, M.; Yao, L. Iron doped effects on active sites formation over activated carbon supported Mn-Ce oxide catalysts for low-temperature SCR of NO. Chem. Eng. J. 2020, 379, 122398. [CrossRef]

10. Gao, C.; Xiao, B.; Shi, J.; He, C.; Wang, B.; Ma, D.; Cheng, Y.; Niu, C. Comprehensive understanding the promoting effect of Dy-doping on $\mathrm{MnFeO}_{\mathrm{x}}$ nanowires for the low-temperature $\mathrm{NH}_{3}-\mathrm{SCR}$ of $\mathrm{NO}_{\mathrm{x}}$ : An experimental and theoretical study. J. Catal. 2019, 380, 55-67. [CrossRef]

11. Li, Y.; Li, Y.; Wang, P.; Hu, W.; Zhang, S.; Shi, Q.; Zhan, S. Low-temperature Selective Catalytic Reduction of $\mathrm{NO}_{x}$ with $\mathrm{NH}_{3}$ over $\mathrm{MnFeO}_{x}$ nanorods. Chem. Eng. J. 2017, 330, 213-222. [CrossRef]

12. Choi, S.K.; Choi, S.W. Low-Temperature Selective Catalytic Reduction of $\mathrm{N}_{2}$ with $\mathrm{NH}_{3}$ over $\mathrm{Mn}_{-} \mathrm{V}_{2} \mathrm{O}_{5} / \mathrm{TiO}_{2}$. J. Phys. Chem. C 2006, 112, 6002-6012.

13. Putluru, S.S.R.; Schill, L.; Jensen, D.A.; Siret, B.; Tabaries, F.; Fehrmann, R. $\mathrm{Mn} / \mathrm{TiO}_{2}$ and $\mathrm{Mn}-\mathrm{Fe} / \mathrm{TiO}_{2}$ catalysts synthesized by deposition precipitation-Promising for selective catalytic reduction of $\mathrm{NO}$ with $\mathrm{NH}_{3}$ at low temperatures. Appl. Catal. B Environ. 2015, 165, 628-635. [CrossRef]

14. Li, G.; Wang, B.; Wang, H.; Ma, J.; Xu, W.Q.; Li, Y.; Han, Y.; Sun, Q. Fe and/or Mn oxides supported on fly ash-derived SBA-15 for low-temperature $\mathrm{NH}_{3}$-SCR. Catal. Commun. 2018, 108, 82-87. [CrossRef]

15. López-Hernández, I.; Mengual, J.; Palomares, A.E. The Influence of the Support on the Activity of Mn-Fe Catalysts Used for the Selective Catalytic Reduction of $\mathrm{NO}_{x}$ with Ammonia. Catalysts 2020, 10, 63. [CrossRef]

16. Shi, Y.; Jiang, K.; Zhang, T.; Guo, J.; Zhao, A. Clean production of porous-Al(OH $)_{3}$ from fly ash. J. Hazard. Mater. 2020, 393, 122371. [CrossRef] [PubMed]

17. Shi, Y.; Jiang, K.; Zhang, T.; Lv, G. Cleaner alumina production from coal fly ash: Membrane electrolysis designed for sulfuric acid leachate. J. Clean. Prod. 2020, 243, 118470. [CrossRef]

18. Li, S.; Gong, H.; Hu, H.; Liu, H.; Huang, Y.; Fu, B.; Wang, L.; Yao, H. Re-using of coal-fired fly ash for arsenic vapors in-situ retention before SCR catalyst: Experiments and mechanisms. Chemosphere 2020, 254, 126700. [CrossRef]

19. Mushtaq, F.; Zahid, M.; Bhatti, I.A.; Nasir, S.; Hussain, T. Possible applications of coal fly ash in wastewater treatment. J. Environ. Manag. 2019, 240, 27-46. [CrossRef]

20. Liu, Z.; Sun, G.; Chen, C.; Sun, K.; Zeng, L.; Yang, L.; Chen, Y.; Wang, W.; Liu, B.; Liu, B.; et al. Fe-doped $\mathrm{Mn}_{3} \mathrm{O}_{4}$ spinel nanoparticles with highly exposed Feoct- $\mathrm{O}-$ Mntet sites for efficient selective catalytic reduction (SCR) of NO with ammonia at low temperatures. ACS Catal. 2020, 10, 6803-6809. [CrossRef]

21. Lei, Z.; Hao, S.; Yang, J.; Zhang, L.; Fang, B.; Wei, K.; Lingbo, Q.; Jin, S.; Wei, C. Study on Denitration and Sulfur Removal Performance of Mn-Ce Supported Fly Ash Catalyst. Chemosphere 2020, 128646. [CrossRef] [PubMed]

22. Cui, R.; Ma, S.; Yang, B.; Li, S.; Pei, T.; Li, J.; Wang, J.; Sun, S.; Mi, C. Simultaneous removal of $\mathrm{NO}_{x}$ and $\mathrm{SO}_{2}$ with $\mathrm{H}_{2} \mathrm{O}_{2}$ over silica sulfuric acid catalyst synthesized from fly ash. Waste Manag. 2020, 109, 65-74. [CrossRef] [PubMed]

23. Liu, J.; Wei, Y.; Li, P.; Zhang, P.; Su, W.; Sun, Y.; Zou, R.; Zhao, Y. Experimental and Theoretical Investigation of Mesoporous $\mathrm{MnO}_{2}$ Nanosheets with Oxygen Vacancy for High-Efficiency Catalytic DeNOx. ACS Catal. 2018, 8. [CrossRef]

24. Tao, W.; Wang, T.; Wan, Z.; Yang, X.; Zhang, X.; Niu, X.; Sun, B. Promotional effect of iron modification on the catalytic properties of Mn-Fe/ZSM-5 catalysts in the Fast SCR reaction. Fuel Process. Technol. 2018, 169, 112-121.

25. Liu, F.; He, H. Structure-Activity Relationship of Iron Titanate Catalysts in the selective Catalytic Reduction of $\mathrm{NO}_{x}$ with $\mathrm{NH}_{3}$. J. Phys. Chem. C 2010, 114, 16929-16936. [CrossRef]

26. Wang, R.; Hao, Z.; Li, Y.; Liu, G.; Zhang, H.; Wang, H.; Xia, Y.; Zhan, S. Relationship between structure and performance of a novel highly dispersed $\mathrm{MnO}_{\mathrm{x}}$ on $\mathrm{Co}-\mathrm{Al}$ layered double oxide for low temperature $\mathrm{NH}_{3}$-SCR. Appl. Catal. B Environ. 2019, 258, 117983. [CrossRef]

27. Wang, F.; Xie, Z.; Liang, J.; Fang, B.; Piao, Y.; Hao, M.; Wang, Z. Tourmaline-Modified FeMnTiO ${ }_{x}$ Catalysts for Improved Low-Temperature $\mathrm{NH}_{3}$-SCR Performance. Environ. Sci. Technol. 2019, 53, 6989-6996. [CrossRef] 
28. Zhang, C.; Chen, T.; Liu, H.; Chen, D.; Xu, B.; Qing, C. Low temperature SCR reaction over Nano-Structured Fe-Mn Oxides: Characterization, performance, and kinetic study. Appl. Surf. Sci. 2018, 457, 1116-1125. [CrossRef]

29. Tian, J.; Zhang, K.; Wang, W.; Wang, F.; Dan, J.; Yang, S.; Zhang, J.; Dai, B.; Yu, F. Enhanced selective catalytic reduction of $\mathrm{NO}$ with $\mathrm{NH}_{3}$ via porous microspherical aggregates of $\mathrm{Mn}-\mathrm{Ce}-\mathrm{Fe}-\mathrm{Ti}$ mixed oxide nanoparticles. Green Energy Environ. 2019, 4, 311-321. [CrossRef]

30. Kapteijn, F.; Singoredjo, L.; Andreini, A.; Moulijin, J.A. Activity and Selectivity of Pure Manganese Oxides in the Selective Catalytic Reduction of Nitric Oxide with Ammonia. Appl. Catal. B Environ. 1994, 3, 173-189. [CrossRef]

31. Wang, G.; Zhang, J.; Liu, L.; Zhou, J.L.; Liu, Q.; Qian, G.; Xu, Z.; Richards, R.M. Novel multi-metal containing $\mathrm{MnCr}$ catalyst made from manganese slag and chromium wastewater for effective selective catalytic reduction of nitric oxide at low temperature. J. Clean. Prod. 2018, 183, 917-924. [CrossRef]

32. Chen, Z.; Wang, F.; Li, H.; Yang, Q.; Wang, L.; Li, X. Low-Temperature Selective Catalytic Reduction of $\mathrm{NO}_{\mathbf{x}}$ with $\mathrm{NH}_{3}$ over Fe-Mn Mixed-Oxide Catalysts Containing $\mathrm{Fe}_{3} \mathrm{Mn}_{3} \mathrm{O}_{8}$ Phase. Ind. Eng. Chem. Res. 2012, 51, 202-212. [CrossRef]

33. Ma, S.; Tan, H.; Li, Y.; Wang, P.; Zhao, C.; Niu, X.; Zhu, Y. Excellent low-temperature $\mathrm{NH}_{3}-\mathrm{SCR}$ NO removal performance and enhanced $\mathrm{H}_{2} \mathrm{O}$ resistance by $\mathrm{Ce}$ addition over the $\mathrm{Cu}_{0.02} \mathrm{Fe}_{0.2} \mathrm{Ce}_{\mathrm{y}} \mathrm{Ti}_{1-\mathrm{y}} \mathrm{O}_{\mathrm{x}}(\mathrm{y}=0.1,0.2,0.3)$ catalysts. Chemosphere 2020, 243, 125309. [CrossRef] [PubMed]

34. Yang, Y.; Wang, M.; Tao, Z.; Liu, Q.; Fei, Z.; Chen, X.; Zhang, Z.; Tang, J.; Cui, M.; Qiao, X. Mesoporous $\mathrm{Mn}-\mathrm{Ti}$ amorphous oxides: A robust low-temperature $\mathrm{NH}_{3}$-SCR catalyst. Catal. Sci. Technol. 2018, 8, 6396. [CrossRef]

35. Wu, Z.; Jin, R.; Liu, Y.; Wang, H. Ceria modified MnO/TiO as a superior catalyst for NO reduction with $\mathrm{NH}$ at low-temperature. Catal. Commun. 2008, 9, 2217-2220. [CrossRef]

36. Wu, Z.; Jiang, B.; Liu, Y. Effect of transition metals addition on the catalyst of manganese/titania for low-temperature selective catalytic reduction of nitric oxide with ammonia. Appl. Catal. B Environ. 2008, 79, 347-355. [CrossRef]

37. Wang, G.; Zhang, J.; Qiang, G. Production of an effective catalyst with increased oxygen vacancies from manganese slag for selective catalytic reduction of nitric oxide. J. Environ. Manag. 2019, 239, 6. [CrossRef] [PubMed]

38. Liu, Z.; Su, H.; Chen, B.; Li, J.; Woo, S. Activity enhancement of $\mathrm{WO}_{3}$ modified $\mathrm{Fe}_{2} \mathrm{O}_{3}$ catalyst for the selective catalytic reduction of $\mathrm{NOx}$ by $\mathrm{NH}_{3}$. Catal. Today 2019, 299, 255-262.

39. Yan, L.; Liu, Y.; Zha, K.; Li, H.; Shi, L.; Zhang, D. Scale-Activity Relationship of $\mathrm{MnO}_{\mathrm{x}}-\mathrm{FeO}_{\mathrm{y}}$ Nanocage Catalysts Derived from Prussian Blue Analogues for Low-Temperature NO Reduction: Experimental and DFT Studies. ACS Appl. Mater. Interfaces 2017, 9, 2581-2593. [CrossRef]

40. Zhang, G.; Huang, X.; Tang, Z. Enhancing Water Resistance of a Mn-Based Catalyst for Low Temperature Selective Catalytic Reduction Reaction by Modifying Super Hydrophobic Layers. ACS Appl. Mater. Interfaces 2019, 11, 36598-36606. [CrossRef]

41. Fan, Z.; Shi, J.; Gao, C.; Gao, G.; Wang, B.; Niu, C. Rationally Designed Porous $\mathrm{MnO}_{\mathrm{x}}-\mathrm{FeO}_{\mathrm{x}}$ Nanoneedles for Low-Temperature Selective Catalytic Reduction of $\mathrm{NO}_{x}$ by $\mathrm{NH}_{3}$. ACS Appl. Mater. Interfaces 2017, 9, 16117. [CrossRef] [PubMed]

42. Guo, M.; Zhao, P.; Liu, Q.; Liu, C.; Han, J.; Ji, N.; Song, C.; Ma, D.; Lu, X.; Liang, X.; et al. Improved low-temperature activity and $\mathrm{H}_{2} \mathrm{O}$ resistance of Fe-doped $\mathrm{Mn}$-Eu catalysts for $\mathrm{NO}$ removal by $\mathrm{NH}_{3}$-SCR. ChemCatChem 2019, 11, 4954-4965. [CrossRef]

43. Fang, N.; Guo, J.; Shu, S.; Luo, H.; Chu, Y.; Li, J. Enhancement of low-temperature activity and sulfur resistance of $\mathrm{Fe}_{0.3} \mathrm{Mn}_{0.5} \mathrm{Zr}_{0.2}$ catalyst for $\mathrm{NO}$ removal by $\mathrm{NH}_{3}-\mathrm{SCR}$. Chem. Eng. J. 2017, 325, 114-123. [CrossRef]

44. Sun, C.; Liu, H.; Chen, W.; Chen, D.; Yu, S.; Liu, A.; Dong, L.; Feng, S. Insights into the Sm/Zr co-doping effects on $\mathrm{N}_{2}$ selectivity and $\mathrm{SO}_{2}$ resistance of a $\mathrm{MnO}_{x}-\mathrm{TiO}_{2}$ catalyst for the $\mathrm{NH}_{3}-\mathrm{SCR}$ reaction. Chem. Eng. J. 2018, 347, 27-40. [CrossRef]

45. Grossale, A.; Nova, I.; Tronconi, E.; Chatterjee, D.; Weibel, M. $\mathrm{NH}_{3}-\mathrm{NO} / \mathrm{NO}_{2}$ SCR for Diesel Exhausts Aftertreatment: Reactivity, Mechanism and Kinetic Modelling of Commercial Fe- and Cu-Promoted Zeolite Catalysts. Catalysis 2009, 52, 1837-1841. [CrossRef] 
46. Gao, Y.; Luan, T.; Zhang, S.; Jiang, W.; Feng, W.; Jiang, H. Comprehensive Comparison between Nanocatalysts of $\mathrm{Mn}-\mathrm{Co} / \mathrm{TiO}_{2}$ and $\mathrm{Mn}-\mathrm{Fe} / \mathrm{TiO}_{2}$ for $\mathrm{NO}$ Catalytic Conversion: An Insight from Nanostructure, Performance, Kinetics, and Thermodynamics. Catalysts 2019, 9, 175. [CrossRef]

47. Zhang, Q.; Zhang, Y.; Zhang, T.; Wang, H.; Ma, Y.; Wang, J.; Ning, P. Influence of preparation methods on iron-tungsten composite catalyst for $\mathrm{NH}_{3}$-SCR of NO:the active sites and reaction mechanism. Appl. Surf. Sci. 2020, 503, 144190. [CrossRef]

48. Lin, M.; An, B.; Niimi, N.; Jikihara, Y.; Nakayama, T.; Honma, T.; Takei, T.; Shishido, T.; Ishida, T.; Haruta, M.; et al. Role of the Acid Site for Selective Catalytic Oxidation of $\mathrm{NH}_{3}$ over $\mathrm{Au} / \mathrm{Nb}_{2} \mathrm{O}_{5}$. ACS Catal. 2019, 9. [CrossRef]

49. Shu, Y.; An, B.; Niimi, N.; Jikihara, Y.; Nakayama, T.; Honma, T.; Takei, T.; Shishido, T.; Ishida, T.; Haruta, M.; et al. Enhancement of Catalytic Activity Over the Iron-Modified $\mathrm{Ce} / \mathrm{TiO}_{2}$ Catalyst for Selective Catalytic Reduction of $\mathrm{NO}_{x}$ with Ammonia. J. Phys. Chem. C 2012, 116, 25319-25327. [CrossRef]

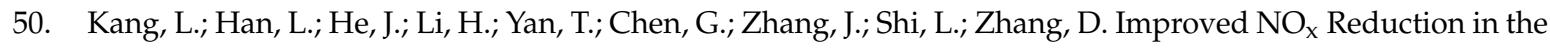
Presence of $\mathrm{SO}_{2}$ by Using $\mathrm{Fe}_{2} \mathrm{O}_{3}$ Promoted Halloysite-supported $\mathrm{CeO}_{2}-\mathrm{WO}_{3}$ Catalysts. Environ. Sci. Technol. 2019, 53, 938-945. [CrossRef]

51. Liu, H.; You, C.; Wang, H. Time-resolved in-situ IR and DFT study: $\mathrm{NH}_{3}$ adsorption and redox cycle of acid site on vanadium-based catalysts for $\mathrm{NO}$ abatement via selective catalytic reduction. Chem. Eng. J. 2020, 382, 122756. [CrossRef]

52. Fu, S.L.; Song, Q.; Yao, Q. Mechanism study on the adsorption and reactions of $\mathrm{NH}_{3}, \mathrm{NO}$, and $\mathrm{O}_{2}$ on the $\mathrm{CaO}$ surface in the $\mathrm{SNCR}$ deNO $\mathrm{x}_{\mathrm{x}}$ process. Chem. Eng. J. 2016, 285, 137-143. [CrossRef]

53. Chen, X.; Liu, Y.; Yang, Y.; Ren, T.; Pan, L.; Fang, P.; Chen, D.; Cen, C. Modified fly ash from municipal solid waste incineration as catalyst support for Mn-Ce composite oxides. IOP Conf. 2017, 81, 012146. [CrossRef]

54. Ren, D.; Gui, K.; Gu, S.; Wei, Y. Study of the nitric oxide reduction of SCR- $\mathrm{NH}_{3}$ on $\gamma \mathrm{Fe}_{2} \mathrm{O}_{3}$ catalyst surface with quantum chemistry. Appl. Surf. Sci. 2020, 509, 144659. [CrossRef]

55. Xie, S.; Li, L.; Jin, L.; Wu, Y.; Liu, H.; Qin, Q.; Wei, X.; Liu, J.; Dong, L.; Li, B. Low temperature high activity of $\mathrm{M}(\mathrm{M}=\mathrm{Ce}, \mathrm{Fe}, \mathrm{Co}, \mathrm{Ni})$ doped $\mathrm{M}-\mathrm{Mn} / \mathrm{TiO}_{2}$ catalysts for $\mathrm{NH}_{3}-\mathrm{SCR}$ and in situ DRIFTS for investigating the reaction mechanism. Appl. Surf. Sci. 2020, 515, 146014. [CrossRef]

56. Zhoua, X.; Yu, F.; Sun, R.; Tian, J.; Wang, Q.; Dai, B.; Dan, J.; Pfeirrer, H. Two-dimensional MnFeCo layered double oxide as catalyst for enhanced selective catalytic reduction of $\mathrm{NO}_{x}$ with $\mathrm{NH}_{3}$ at low temperature (25-150 ㄷ). Appl. Catal. A Gen. 2020, 592, 117432. [CrossRef]

57. Gao, E.; Huang, B.; Zhao, Z.; Pan, H.; Zhang, W.; Li, Y.; Bernards, M.T.; He, Y.; Shi, Y. Understanding the co-effects of manganese and cobalt on the enhanced SCR performance for $\mathrm{Mn}_{\mathrm{x}} \mathrm{Co} 1-\mathrm{xCr} \mathrm{O}_{4}$ spinel-type catalysts. Catal. Sci. Technol. 2020, 10, 4752-4765. [CrossRef]

58. Gu, J.; Zhu, B.; Duan, R.; Chen, Y.; Wang, S.; Liu, L.; Wang, X. Highly dispersed MnOx-FeOx supported by silicalite-1 for the selective catalytic reduction of $\mathrm{NO}_{x}$ with $\mathrm{NH}_{3}$ at low temperatures. Catal. Sci. Technol. 2020, 10, 5525-5534. [CrossRef]

Publisher's Note: MDPI stays neutral with regard to jurisdictional claims in published maps and institutional affiliations.

(C) 2020 by the authors. Licensee MDPI, Basel, Switzerland. This article is an open access article distributed under the terms and conditions of the Creative Commons Attribution (CC BY) license (http://creativecommons.org/licenses/by/4.0/). 